\title{
Barroco, neobarroco e outras ruínas
}

\author{
João Adolfo Hansen
}

Resumo O texto propõe que a reconstituição dos códigos bibliográficos, dos códigos retórico-poéticos e dos condicionamentos materiais e institucionais das representações luso-brasileiras do século XVII não necessita da noção dedutiva de "barroco" que as classifica universalizando categorias críticas próprias do contínuo e da psicologia idealistas. Palavras-chave Barroco » Gregório de Matos " retórica poética.

\footnotetext{
Abstract This paper argues that the reconstitution of bibliographical codes, rhetorical-poetical codes and material and institutional conditions of XVII ${ }^{T H}$ century Luso-Brazilian representations does not need the deductive notion of "baroque" applied to their classification, for the notion universalizes critical categories that are specific of idealistic continuum and psychology. Key words Baroque " Gregório de Matos » poetical rhetoric.
} 
-Esse é o professor que trabalha com o barroco.

-Prazer.

- Muito prazer.

-Mas... é o barroco histórico...

$-A h \ldots$

[Num corredor]

"Qui t' a faite? pensai-je. Tu ne ressembles à rien, et pourtant tu n es pas informe"

[Paul Valéry. Eupalinos ou L'Architect. Oeuvres]

Estado da questão Acredito, como Alan Boase ${ }^{1}$, que é inútil fazer mais uma vez a etimologia do termo "barroco" para buscar definições mais precisas dele na uerruca da História Natural de Plínio, no silogismo escolástico e na pérola irregular. Fazê-lo lembra o trabalho de colecionar borboletas em gavetas previamente classificadas, como ocorre nos usos dedutivos e a-críticos da noção estilística de "barroco" para classificar e unificar as representações ${ }^{2}$ luso-brasileiras do século XVII com categorias estético-políticas exte-

1 BOASE, Alan. "Réflexions sur la problématique spécifique du Baroque". In: Renaissance Maniérisme Baroque. Paris: Vrin, 1972, p. 39.

2 Na sociedade luso-brasileira do século XVII, a identidade é definida como representaçāo - uma forma especifica da posição - e pela representação - uma ocasião de sua aplicação como aparência decorosa subordinada no corpo mistico do Império Português. Por “representaçāo", no caso, entendo quatro coisas: 1. O uso particular, em situação, de signos no lugar de outra coisa. Nas representaçōes luso-brasileiras do século XVII, os signos são recortados em uma matéria qualquer como imagens de conceitos produzidos na substância espiritual da alma participada pela substância metafisica de Deus. 2. A aparência ou a presença da coisa ausente 
riores a elas3. O "barroco" nunca existiu historicamente no tempo classificado pelo termo, pois "barroco" é Heinrich Wölfflin e os usos de Wölfflin. Melhor dizendo, a noção só passou a existir formulada positivamente, em 1888, na obra admirável de Wölfflin, Renascimento e Barroco, como categoria neokantiana apriorística em um esquema ou morfologia de cinco pares de oposições de "clássico" e "barroco" aplicados dedutivamente para apresentar alguns estilos de algumas artes plásticas dos séculos XVI e XVII. Antes de Wölfflin, em 1855, indiciando o crescente interesse pela noção, Jacob Burckhardt havia proposto que o Barockstyl era um "dialeto selvagem" da linguagem renascentista. Riegl falou de "tátil" e "visual". E, na crítica ao filisteísmo alemão, Nietzsche afirmava que falar mal do "barroco" era uma atitude de pedantes. Wölfflin retomou a noção, nos Princípios fundamentais da história da arte, de 1915, como categoria de uma Kunstwissenschaft, uma ciência da arte. No esquema, "barroco" aplica-se dedutivamente a alguns estilos em que predomina o pictórico ou a massa acumulada da cor confundida, como acontece na pintura de Rubens, que exigiria observação dinamicamente minuciosa de formas misturadas que se subordinam a um único ponto de vista. Por oposição, "clássico" compõe, também dedutivamente, artes em que predomina a linha do desenho nítido que prescreve a observação quase estática de superfícies coordenadas de formas claras e distintas, como na pintura não-penumbrista de Rafael. A morfologia lineariza os estilos artísticos como unidades consecutivas sobre o eixo de um contínuo temporal, "clássico" antes, "barroco" depois4, não admitindo a coexistência historicamente observável de múltiplos estilos, como ocorre nos casos de Michelangelo, Caravaggio, Poussin, Bernini5,

» produzida na substituição. 3. A forma retórico-poética da presença da ausência. 4. A posição hierárquica encenada na forma como tensão e conflito de representações.

3 Uso a expressão "século XVII" para classificar descritivamente a duração da "política católica" da colonizaçāo ibérica anti-maquiavélica e anti-luterana, cujos limites podem ser 1580, início da União Ibérica, e 1750, ano da morte de D. João v e inicio das transformações políticas e culturais do despotismo ilustrado do Marquês de Pombal. As datas são indicativas, podendo-se recuá-las ou avançá-las segundo as várias estruturas de durações e extensões diversas e diferentes que coexistem no recorte. Se algumas aparecem como longuíssimas durações de referências e modelos gregos, latinos, patrísticos, escolásticos e neo-escolásticos, principalmente, que desaparecem por volta do final do século XVIII, outras continuam sendo transformadas fora do limite cronológico desse recorte. É o caso de modelos artísticos italianos e ibéricos quinhentistas e seiscentistas aplicados na arquitetura, na escultura e na pintura do final do século XVIII e início do XIX.

4 A partir de 1920, fala-se de "Maneirismo", unidade estilística posta entre o Renascimento e o Barroco, como classificação, por exemplo, de emuladores da maniera de Michelangelo Buonarrotti. Curtius propōe "maneirismo" como invariante transistórica, entendendo "barroco" como uma de suas espécies.

$12 \neg$ João Adolfo Hansen 
nos recortes cronológicos unificados pelas oposições, como formas produzidas por uma emulação que transforma tópicas retóricas e procedimentos técnicos de sedimentos e modelos egípcios, gregos, alexandrinos, latinos, bizantinos, patrísticos, escolásticos, neoescolásticos e um enorme etc., simultâneos e de duração diversa e diferente; também não admite a existência de composições em que os procedimentos técnicos e os efeitos de significação das artes classificadas pelas oposições aparecem mesclados ou combinados.

Desde que Wölfflin usou o termo como categoria estética positiva, a extensão dos cinco esquemas constitutivos de "barroco" - pictórico, visão em profundidade, forma aberta, unificação das partes a um todo, clareza relativa - passou a ser ampliada, aplicando-se analogicamente a outras artes do século XVII, como as belas letras, apropriadas como "literatura barroca" em programas modernistas e estudos de tropos e figuras feitos segundo a conceituação romântica de retórica como estilística restrita à elocução psicologicamente subjetivada, para em seguida classificar e unificar as políticas, as economias, as populações, as culturas, as "mentalidades" e, finalmente, sociedades européias do século XVII, principalmente as ibéricas contra-reformistas, com suas colônias americanas, na forma de essências: "o homem barroco", "a cultura barroca", "a sociedade barroca" etc. Dedutivas e exteriores, as apropriações a-críticas de Wölfflin substancializam a categoria, constituindo "barroco" como fato e essência que existem em si, ante rem, levando a que rotineiramente se pergunte se tal autor, monumento, quadro, livro ou poema são "barrocos". Feitos sem crítica documental sobre a produção das letras e artes no século XVII, sem crítica documental dos modos como os resíduos delas foram selecionados, conservados e transmitidos desde o século xvilı e, ainda, sem crítica genealógica da invenção da categoria no final do século xix e das suas apropriações posteriores, os usos de "barroco" na crítica e na história literária não consideram, geralmente, que a noção não tem existência independente do corpus neokantiano aplicado para defini-la ${ }^{6}$ no final do século XIX, nem dos lugares institucionais que a aplicam, nem, ainda, dos condicionamentos históricos dos objetos particulares do século Xvir a que se aplica. Para que a definição e o uso do termo fossem pelo menos aceitáveis, seria necessário que características ditas "barrocas" especificassem todas as obras de uma série determinada e apenas a elas; no entanto, as séries classificadas como "barrocas" são bastante diversas e diferentes de lugar para lugar, de autor para autor, e, principalmente, de uma arte para outra e mesmo de obras para obras de um mesmo autor, de modo que características formais propostas

5 Cf. KOSSOVITCH, Léon. O barroco inexistente. Entrevista com Joaci Pereira Furtado. CULT. Revista Brasileira de Literatura (São Paulo), Lemos Editorial, p. 60-1, maio 1998.

6 MIGNOT, Claude. Un monstre linguistique. L'Âge du Baroque. Magazine Littéraire n. 300 (Paris), p. 42, juin 1992.

Barroco, neobarroco e outras ruinas $\ulcorner 13$ 
como específicas de "barroco", quando a noção se aplica às representações do século XVII, não passam de generalidades formuladas como deduções e analogias - informalidade, irracionalismo, pictórico, fusionismo, contraste, desproporção, deformação, acúmulo, excesso, exuberância, dinamismo, incongruência, dualidade, sentido dilemático, gosto pelas oposições, angústia, jogo de palavras, niilismo temático, horror do vácuo - que explicitam mais as disposições teórico-ideológicas dos lugares institucionais que as aplicam que propriamente a estrutura, a função e o valor históricos dos objetos a que são aplicadas, na medida mesma em que, sendo genéricas, como resultados de esquemas universalizados a-criticamente sem fundamentação empírica, também poderiam ser aplicadas a qualquer outra arte de qualquer outro tempo.

Aqui, porém, não me interessa negar a existência de "barroco" nem propor que não se use o termo. Como dizia Deleuze, é estranho negar a existência de "barroco", como se negam unicórnios e elefantes rosa. No caso destes, o conceito já está dado, mas não no caso de "barroco", em que seria útil saber se é possível inventar um conceito capaz de lhe conferir existência no século xvi17. Para demonstrar que não, basta propor o conceito que existe, e que é o positivado por Wölfflin, e, depois, pelo historicista espanhol Eugénio D'Ors, que em estudos kardecistas desmaterializou de vez a generalidade dedutiva do esquema, afirmando que "O Barroco" Constante Universal do Espírito Humano, desencarna-se em sua obra quando nela reencarna "Clássico" várias vezes, desde a PréHistória. Certamente, o termo pode ser usado como se usa qualquer outra etiqueta arbitrária para classificar operatória e descritivamente um corpus determinado. São criticáveis seus usos quando implicam a classificação e a unificação dedutivas e transistóricas das representações das letras do século xviI; ou seja, os usos que, generalizando o apriorismo do esquema wölffliano e sua desistoricização definitiva por D’Ors, desqualificam ou valorizam as representações com critérios neoclássicos, românticos e positivistas universalizados como "excesso" "deformação", "ruptura" "angústia", "acúmulo", "jogo de palavras", "hermetismo", "mau gosto", "afetação" considerando as formas passadas como etapas para si mesmos e, por isso, concebendo-as de maneira unilateral 8 Por exemplo, nas histórias literárias escritas segundo o pressuposto teleológico de que as

7 DELEUZE, Gilles. Le Pli. Leibniz et le Baroque. Paris: Minuit, 1988, p. 47.

8 No sentido de Marx: "O assim chamado desenvolvimento histórico fundamenta-se em que a última forma considera as formas passadas como etapas para si mesma. E sendo esta forma raramente e apenas em condições determinadas capaz de criticar-se a si mesma - nāo se trata aqui daqueles períodos históricos que se apresentam a si mesmos como tempos de decadência - ela as concebe sempre de maneira unilateral"(MEW, vol. 13, p.636).

$14 \neg$ João Adolfo Hansen 
mudanças estéticas alinham-se como superações que expressam o nacional, "barroco" é etapa, "O Barroco", do contínuo sobre o qual as letras, unificadas como estilo de época, vão-se sucedendo umas depois de outras, retornando ao sujeito transcendental kantiano ou ao espírito absoluto hegeliano. Uma teoria que pressupõe a objetivação de si mesma como esquema prévio aplicado aos objetos não pode ser usada em nenhum trabalho de análise histórica. E nenhum trabalho de análise histórica é factível sem uma progressiva sistematização simultânea das informações documentais, que implica um pensamento crítico em contínua (auto)verificaçãos. A noção apriorística ou dedutiva de "barroco" é descartável, enfim, ainda que muitas de suas reencarnações até possam ser curiosamente folclóricas como o elefante rosa.

Usos de "barroco" Observou-se nos últimos 20 anos um interesse crescente e polêmico pelo "barroco", que retornou com alguma insistência em práticas artísticas ${ }^{10}$ e críticas ${ }^{11}$ contemporâneas identificadas muitas vezes como "neobarrocas", "pós-modernas" e

9 FOUCAULT, Michel."Le sujet et le pouvoir". In: Dits et écrits 1954-1988. Ed. établie sous la direction de Daniel Defert et François Ewald. Paris: Gallimard, 1994, 4 V., vol. IV, 1980-1988, p. 223.

10 Usos poéticos de "barroco"e "neobarroco" são operatórios, como o "neobarroso"na foz do Rio da Prata, de Néstor Perlongher; o "barroco" como "simbiose" ou "mestiçagem" contínuas que engendram "barroquismo", segundo Alejo Carpentier, para quem as pirâmides de Teotihuacán também são "barrocas". Um uso muito influente de "barroco" é o do "presente de produção" poética e artística proposto por Haroldo de Campos. No caso, "neobarroco" significa a novidade contemporânea produzida por uma invenção artística que, apropriando-se sincronicamente de procedimentos técnicos e efeitos das artes do século XVII, usa-os como matéria de transformações poéticas. O nome "neobarroco" dos objetos estéticos é posto por meio de analogias estabelecidas entre seus efeitos e os efeitos das artes do passado classificadas como "barroco". Na apropriação poética dos restos, propõe-se, com Jauss، Iser, Paz, Sarduy e outros, a exemplo do que T.S. Eliot fez com a poesia de Donne e Marvell, ou Garcia Lorca com a de Góngora, que o conhecimento da poesia de Mallarmé, por exemplo, permite ao poeta contemporâneo reconhecer o valor estético da poesia de Góngora, que é constituído retrospectivamente como precursor. Não é o asianismo de Góngora, no final do século XVI, que antecipa as divisões prismáticas da Idéia da poesia de Mallarmé, no XIX, mas a leitura de Mallarmé por um poeta do século XXI que permite constituir a poesia de Góngora como uma tradição do novo ou de determinado modo contemporâneo de compor poesia segundo um cânone poético "de invençāo". Da mesma maneira, conhecendo a antropofagia cultural de Oswald de Andrade, o poeta contemporâneo pode classificar poeticamente, com uma metáfora, as mesclas estilísticas da sátira de Quevedo ou da poesia atribuída a Gregório de Matos Guerra como "antropofagia cultural", quando se apropria delas para produzir mistos estilísticos chamados de "neobarrocos". Poeticamente, como termo que especifica um programa estético, "neobarroco" indica procedimentos específicos de

Barroco, neobarroco e outras ruínas $\ulcorner-15$ 


\section{"pós-utópicas"12. O retorno produziu e produz várias unilateralidades ${ }^{13}$. O termo "neobar- roco" significa "novo barroco" e implica a existência de um intervalo temporal entre o pre- sente, que enuncia o "neo", e algo que seria um passado, "o barroco" entendido nos termos}

" práticas de apropriação do passado na invenção artistica contemporânea. Os usos da noção são discutíveis, contudo, quando as metáforas da fiç̧ão ou da prática poética são transferidas para o discurso crítico e historiográfico, afirmando-se por exemplo que Gregório de Matos é um antropófago cultural ou, como se diz hoje na Bahia, um antropólogo-eclético-sincrético-pluriétnico-multicultural. Muitas feridas narcísicas permaneceriam incólumes se as pragmáticas poéticas, críticas e historiográficas, que usam os termos "barroco" e "neobarroco", fossem definidas. A poesia é sempre histórica, mas o discurso da poesia não é o discurso da história. A identifcaçāo de ficção e história tem conseqüências políticas graves e já foi suficientemente questionada. Em usos historiográficos, a aplicação de categorias iluministas e pós-iluministas às representações luso-brasileiras do século XVII é evidentemente anacrônica, supondo-se a irredutibilidade da diferença histórica das práticas substancialistas de uma monarquia católica absolutista aos esquemas teleológicos e ilustrados da respublica que todos, suponho, desejamos democrática também quando é república das letras.

11 Críticas às vezes engenhosas. Recentemente, identificando "barroco" com "curva", um crítico do Rio escreveu que as pernas de Garrincha eram "barrocas". Apesar disso, podia-se acrescentar, marcaram gols "clássicos". Outro, poeta e crítico de artes plásticas, já tinha proposto que as montanhas de Minas Gerais sāo "barrocas". E por aí vai.

12 Por exemplo, na expressão "América Barroca", que retoma as conceituações da obra de Richard Morse, como o livro O Espelho de Próspero, que trata da especificidade da colonização inglesa da América do Norte, comparando-a com a colonização ibérica, propōe-se a continuidade transistórica do ethos corporativista da colonização ibérica. A continuidade explicaria, por exemplo, a natureza de práticas de conciliação política da assim chamada "América Latina", como é o caso da federação das diferenças tucanas e oligárquicas comandadas pela cabeça real do Banco Mundial. Nos usos em que "barroco" e "neobarroco" significam a continuidade transistórica do ethos ibérico, típico da doutrina católica do poder monárquico absolutista, caracterizado pela indistinção de público/privado, pelo providencialismo e milenarismo messiânico, pelo corporativismo, pela delegação da autoridade e pelo favor como mediação universal das relações sociais, o "neobarroco", suposto como característica principal da cultura "neobarroca" contemporânea, significa a fatalidade da natureza colonial do país, segundo um pressuposto indeterminado e metafísico, como o éon "barroco" ou o Universal do Espírito Humano de D'Ors.

13 Na Formação da Literatura Brasileira, Antonio Candido não inclui o assim chamado "barroco", tendo sido criticado por tê-lo "seqüestrado", como se lê em O seqüestro do barroco na formação da literatura brasileira: o caso Gregório de Mattos, de Haroldo de Campos (Salvador: Fundação Casa de Jorge Amado, 1989). Acredito que, dando conta de um projeto histórico caudatário da Bildung do idealismo alemão, o trabalho histórico de Candido não podia incluir o chamado "barroco", pois as representações que passaram a ser assim classificadas no

$16 \neg$ João Adolfo Hansen 
de Wölfflin, também chamado de "barroco histórico", ou seja, as ruínas do século XVII. Por sua vez, "barroco histórico" parece significar duas coisas: a primeira, que houve algo efetivamente histórico, como "o barroco", na chave de Wölfflin; a segunda, que há "barrocos" que não são históricos. Assim, por vezes o termo "barroco" de "neobarroco" também significa uma estrutura intemporal, “O Barroco”, entendida segundo a metafísica de D’Ors. Lembrando-se que "barroco" é uma invenção neokantiana e positivista do século XIX e que o século Xviı não foi "barroco", o termo "neobarroco", como "novo barroco", também significa - em todos os casos - o futuro de um pretérito que não houve ou pelo menos o futuro do neokantismo de Wölfflin como um neo-neokantismo. Os diversos e diferentes usos da noção parecem indicar que há vários modelos de inteligibilidade aplicados segundo pragmáticas diversas. 14 Em todos, a identidade dedutiva de "barroco" ou "barroco histórico" é operada por meio de analogias estabelecidas entre efeitos descontínuos e críticos da racionalização negativa da forma moderna e da desierarquização "eclética" do valor estético da informalidade pós-moderna com os efeitos das agudezas retóricas do conceito engenhoso do século XVII. Os usos dedutivos, a-críticos, analógicos e transistóricos de "barroco" são obviamente históricos, incluindo-se em programas políticos de apropriação do passado colonial objetivamente interessados na produção de tradições nacionalistas 15 e desistoricizações neoliberais. ${ }^{16}$

》 século XX eram entendidas pelos agentes históricos do processo de Bildung, a partir do final do século XVIII, como representações despóticas, próprias do Antigo Estado português, ou seja, exteriores ao projeto.

14 É sabido que em países da América Espanhola, como Cuba, México, Peru, intelectuais e artistas usam o termo "barroco" programaticamente, de modo afirmativo, para conceituar uma cultura criolla miscigenada. Lezama Lima falou do "señor barroco", recusando a transistoricidade da metafísica de D'Ors, para significar a cultura de resistência política do criollo como originalidade americana ou "arte da contraconquista", que enfrentou e enfrenta o imperialismo de culturas hegemônicas. Neste sentido, "barroco" significa a fusão de culturas já nos séculos iniciais da invasão e conquista das novas terras pela Espanha. É útil, contudo, especificar histórica e antropologicamente os modos como foi realizada, problematizando-se o racismo implícito na idéia de"miscigenação", quando esta é formulada pressupondo "purezas" étnicas e culturais européias e indígenas anteriores à conquista da América.

15 A interpretação de "barroco" mais generalizada no ensino superior e médio é a da tradiçāo romântica e hegeliana proveniente dos antiquários do século XVIII, que assimilaram idéias de Herder e dos irmãos Schlegel, principalmente do Friedrich Schlegel convertido ao catolicismo, que, a partir de 1812, renegou sua teoria critica anterior, que definia a poesia como universal progressivo ou revolução permanente da forma, quando fez, em Viena, as conferências sobre as literaturas antigas e modernas, incluindo a crítica das obras literárias no movimento de construçāo do Estado nacional alemāo. A constituição da história literária significa, obvia-

Barroco, neobarroco e outras ruinas $\ulcorner-17$ 
» mente, a constituição da Literatura e da sua historicidade. Assim, no programa nacionalista de formação do "povo" e organizaçăo da cultura por intelectuais orgânicos, a história literária sistematizada por Schlegel revela o Geist, o Espírito, a Weltanschaaung, a visão de mundo, de vários momentos da história nacional orientados como expressão e progresso. Sempre acompanhado de crítica estética, o gênero pressupõe que as obras artísticas são uma mediação que expressa conteúdos da realidade social em sua evolução, sendo objeto de uma hermenêutica que revela a originalidade do caráter nacional para um público instado a conscientizar-se do mesmo, integrando-se ao processo. O gênero da história literária assim realizado costuma abstrair tanto a materialidade dos suportes e dos meios de transmissão das obras quanto a especificidade histórica das práticas produtivas da forma, que é simples meio para o Conteúdo nacional. Transformado em factualidade positivista ainda no século XIX, o gênero reduz o estético a ilustração documental de um sentido pretotalizado como "caráter nacional" expresso na raça e na psicologia do artista-gênio. A história literária organizada segundo essa matriz faz de cada momento da cultura uma etapa para estágios posteriores e superiores, mantendo-se atuante, de forma inercial e quase sempre impensada, nas categorias psicologistas que, a partir do século XX, operando dedutivamente com a noção de "barroco" e "neobarroco", dão continuidade ao pressuposto romântico-nacionalista claramente exposto por Gonçalves de Magalhāes no “Discurso histórico sobre a literatura brasileira", publicado na revista Niterói, em 1836, em Paris. Nesse texto, como se sabe, Magalhães constrói uma alegoria da cultura brasileira, que organizava com outros intelectuais do IHGB, na forma de uma montanha circundada por um caminho ascendente. Conforme Magalhães, ele e os autores do seu tempo ainda se acham na base, mas, subindo, fazem subir, com a missão civilizatória que define a literatura brasileira como "indígena civilizada". Segundo o autor, os autores coloniais, caracterizados pelo artificialismo retórico da imitação de modelos metropolitanos, não teriam sabido ou querido representar a "realidade brasileira" já caracterizada, em tempos coloniais, pelo caráter nacional cujo telos, posto na origem do país no século XVI, integra o local à religião cristã e à civilização européia. A maioria dos autores coloniais ficaram alienados do ethos nacional devido ao artificialismo da imitação de modelos metropolitanos, mas houve prenúncios do mesmo em descriçōes da natureza e críticas esparsas à predação colonialista. O resgate desses prenúncios pela história literária compõe as expressões sucessivas e progressivas dessa natureza, física e humana, fazendo da literatura um instrumento progressista de formação da jovem nação tutelada pelo Imperador Pedro ॥ no seu manto de tucano real. É o telos nacionalista que determina, nessa historiografia, os critérios de definição do que seja o evento representável válido, visível e dizível, e a qualidade estética positiva da arte que o representa. No caso da historiografia literária romântica, o telos leva a pinçar aqui e ali, nas obras coloniais, exemplos do ideal preformado pelo intérprete em uma retrospeç̧ão que transforma autores coloniais em protonacionalistas, como ainda ocorre agora na folclorização da poesia chamada Gregório de Matos. Como o fim está dado no princípio, as obras são eventos reveladores da necessidade ideal que avança para a sua plena realização futura. Por outras palavras, sendo modelada como retrospecção de prefigurações de um ideal, a história literária romântica permanece teológica, lembrando o figural da interpretação cristã. Nos casos de obras coloniais em que a prefiguração não ocorre, o tempo anterior à independência é constituído por meio de catego-

$18 \neg$ João Adolfo Hansen 
É útil lembrar que, na morfologia de Wölfflin, "clássico" é definido como "formal". Logo, "barroco" implica "informalidade". A suposta "informalidade", no sentido dedutivo da categoria, foi programaticamente apropriada na vanguarda expressionista alemã, no começo do século $\mathrm{xx}$, sendo desde então psicologizada neo-romanticamente, positiva e negativamente, como "irracionalismo" expresso, segundo inúmeras interpretações, no "excesso", no "acúmulo" e na "desproporção" da forma. Muitas vezes, em leituras psico-

》) rias espaciais como um espaço homogêneo e vazio, que importa e imita artificialmente, sem transformaçāo, as representaçōes metropolitanas. A mesma representaçāo colonial torna-se, por assim dizer, exterior à "realidade brasileira" pressuposta no local como "nacional". O próprio evento da representação perde sua especificidade de prática datada e situada, pois é absorvido na essência que o explica dedutivamente. A especificidade histórica das práticas locais não é considerada, quando sāo apropriadas como mediação ou etapas para o estágio superior, que as considera representativas. Quando as representações são transformadas em "barroco", no século xx, a interpretação nacionalista tende a ser mantida no uso dedutivo e a-crítico da noçāo. A respeito da historiografia literária Cf. BOSI, Alfredo. "Por um historicismo renovado: reflexo e reflexão na história literária". Teresa. Revista de Literatura Brasileira (São Paulo), DLCV-FFLCH-USP, 19̣ semestre de 2000, n. 1, págs. 9-47; COSTA LIMA, Luiz. Auerbach e a História Literária. Cadernos do Mestrado 2 (Rio de Janeiro), Depto. de Letras, UERJ, 1992, P.3-34; Limites da Voz. Montaigne, Schlegel. Rio de Janeiro: Rocco, 1993.

16 Na chave dos cultural studies norte-americanos, afirma-se também que o "barroco" teria sido adaptativo, flexível como uma coluna vertebral, sem doutrina e oposição cultural de espécie alguma. Um exemplo dessa ideologia pode ser lido no texto do catálogo da exposição Barroco Brasileiro organizada pelo governo brasileiro no Petit Palais de Paris, em 1999, que traduzo:

“Esta vitalidade sem fronteira do barroco, esta ductilidade e esta maleabilidade, que lhe permitem adaptar-se aos mais diversos contextos sócio-culturais, políticos e geográficos e às mais opostas tradiçōes culturais e espirituais se explicam sem dúvida por seu caráter de arte sem doutrina. (...) Os contemporâneos do barroco jamais fizeram a teoria do barroco (diferentemente do que se passou com o Renascimento, o Classicismo, o Neoclassicismo); este vazio doutrinário, que dribla nossos esforços de definiçāo, faz do barroco uma arte que não se opõe a nenhuma outra, mas que se adapta a todas as situaçōes". Cf. POMMIER, E. "Barroco Brasil Barroco". In: Brasil Barroco. Entre céu e terra. Paris: Petit Palais, União Latina، 1999/2000, p. 42.

O texto classifica autores luso-brasileiros de artes e outros do século XVII e XVIII como "barrocos" e afirma que nunca fizeram a doutrina do "barroco". A afirmação seria justa, se a expressāo" vazio doutrinário" se referisse à impossibilidade de homens do século xvı pensarem em Kant, Comte, Wölfflin e Fukuyama. Mas nāo se trata disso. O texto constitui os autores do século XVII como ignorantes de si mesmos e do que fizeram em seu tempo, ferindo a memória de grandes cabeças, como por exemplo Galileo, Possevino, Gilio, Ripa, Valeriano, De Soto، Bellarmino, Botero، Suárez, Borromeu, Cajetano, Acquaviva, Marino, Accetto, Pallavicino, Otonelli, Peregrini, Tesauro, Góngora, Quevedo, Gracián, Jáuregui, Lope, Saavedra Fajardo, Palafox, Sigüenza y Góngora,

Barroco, neobarroco e outras ruínas -19 
existencialistas, o suposto "irracionalismo" é "angústia" de suposta psicologia do Dasein "barroco" tragicamente dilacerado, por exemplo, pelo mecanicismo reflexológico de Arnold Hauser e pelo sociologismo togado de Lucien Goldmann. Dizendo-o de outro modo, quando as apropriações classificam os resíduos do século XviI como "barrocos", no sentido wölffliano-neokantiano da categoria, a suposta "informalidade" de "forma aberta" e "dinamismo" e o suposto "irracionalismo" de "pictórico" e "clareza relativa" são sobrepostos à particularidade das práticas produtivas das representações, deslocando e obliterando sua formalidade de prática. Em seu tempo, eram produzidas pela aplicação de técnicas racionais, que prescreviam os processos e os procedimentos da sua invenção, publicação e consumo. $\mathrm{O}$ apagamento da mediação técnica faz entender os efeitos calculados das representações ditas "barrocas" por meio do patetismo psicológico da ironia romântica e do realismo de concepções empiricistas, generalizando transistoricamente as categorias do idealismo alemão na base das interpretações. As aplicações do esquema "informalidade" também fazem entender que o suposto "irracionalismo" supostamente expresso em efeitos supostamente "excessivos" resulta da unidade contraditória de suposta superestrutura ideológica do século XVII, "a mentalidade barroca”, e de uma também suposta subjetividade psicológica que se angustiou nela, "o homem barroco" Segundo as apropriações, que apagam a especificidade política e retórico-poética da produção dos efeitos das representações ditas "barrocas” em seu tempo, a consciência possível do "homem barroco" se retorceu em imagens alambicadas, artificiais, ociosas, fátuas, pedantes, sem relação orgânica com sua realidade, expressando de modo complicado,

» Sor Juana Inés de la Cruz, D. Francisco Manuel de Melo, Vieira, Francisco Leitão Ferreira, Grimmelshausen, Gryphius, Athanasius Kircher e um extenso etc., que doutrinaram magnificamente o que praticaram, para afirmar que o "barroco" é "uma arte que não se opõe a nenhuma outra, mas que se adapta a todas as situações". A produção da ignorância do suposto "barroco" quanto a si mesmo no seu tempo, os séculos XVII e XVIII, produz outra, específica do presente em que a formulação é feita: consiste em propor ao público da exposição do Petit Palais e aos leitores dos textos do catálogo sobre Brasil Barroco o caráter adaptativo, integrativo e sem conflitos do assim chamado "barroco" na sociedade colonial "barroca" dos séculos XVII e XVIII e, supondo-se que o Brasil faz parte da "América Barroca", na sociedade brasileira "neobarroca" e neocolonialneoliberal do ano 2000. Uma leitura superficial de ordens-régias, regimentos de governadores, atas de Câmaras municipais, sátiras atribuídas a Gregório de Matos, cartas jesuíticas sobre a catequese, documentos que regulam o tráfico e o castigo exemplar de escravos, denúncias à Inquisição etc. etc. demonstraria que essa "arte que não se opõe a nenhuma outra" sempre põe em cena a hierarquia e os processos de dominação, como integração, subordinação e exclusão forçadas de índios, negros, mulatos, judeus, cristãos-novos, pobres e outros plebeus como membros do corpo místico do Império Português.

$20 \neg$ João Adolfo Hansen 
mas não complexo, o real do seu tempo. A determinação desses expressionismos angustiados é explicada no caso luso-brasileiro, geralmente, pelo fato de "o homem barroco" que já era um Brasileiro vivendo numa colônia do Império Português no século XVII ter chegado demasiado cedo para a ciência empirista inglesa em sua sociedade atrasada, que desde o século xvi já tinha perdido o bonde da História de mão única com firulas aristotélicas e neo-escolásticas, e demasiado tarde para a fé cristã, em sua sociedade abalada pelo maquiavelismo efetivo das políticas mercantilistas de potências realmente modernas, França, Holanda e Inglaterra. O esquema evolucionista de uma história única feita como supra-história de atrasos e progressos dedutivamente aplicados põe a "angústia" do "homem barroco" depois de "Renascimento", que sucedeu a "Idade Média", como expressão da tentativa inútil de conciliar as generalizações românticas dos intérpretes, $o$ Teocentrismo da Idade Média e o Antropocentrismo do Renascimento.

Para os autores e públicos do século XVII, contudo, era básica a fruição de imagens plásticas e visualizantes, de efeitos contrastivos e grande intensidade dramática, tendendo ao sublime, nos gêneros altos, e ao monstruoso e infame, nos mistos dos baixos. Como imagens retóricas, eram extraídas de repertórios ou elencos prefixados, valorizando-se a novidade de sua recombinação em usos inesperados. Hoje, podem parecer mecânicas e frias ou excessivamente elaboradas, com um rebuscamento intelectualista que costuma ser objeto de juízos negativos, uma vez que o romantismo que forma a cultura do país induz a crer que todo trabalho de desproporção e acúmulo é sintoma de alguma espécie de dilaceramento, logo identificado em termos psicológicos e psicologistas, quando não psicopatológicos. A fortuna crítica de Gregório de Matos e Guerra é exemplar desse patetismo retrospectivo que projeta na técnica retórica da maledicência da persona satírica a psiquiatria do ressentimento e pessimismo atribuídos ao homem, autor suposto. Se não se considera que as imagens dos discursos seiscentistas estão dispostas como entimemas ou silogismos retóricos, como esquemas figurativos de conceitos de uma invenção analisada segundo leis dialéticas de definição, contradefinição e argumentação, os discursos são reduzidos ao critério expressivo. O que é plausível em termos heurísticos, mas anacrônico, em termos históricos. Pelo critério expressivo, as imagens das representações coloniais serão avaliadas conforme seu maior ou menor afastamento da "naturalidade sem artifício" pressuposta no tratamento romântico de temas, e, ainda, conforme sua maior ou menor clareza, entendida neoclassicamente como transparência da formulação de idéias claras, distintas e sensatas da consciência do autor, que formam a base dos juízos negativos correntes na crítica e na historiografia literárias brasileiras de determinação romântico-iluminista. Não será considerado, então, que a falta de clareza suposta corresponde, no século XVII, à variedade de processos de argumentação disponíveis segun-

Barroco, neobarroco e outras ruínas -21 
do padrões retóricos coletivizados e objetivados em práticas de representação como prescrições de usos sociais de vários hermetismos e clarezas posicionais, adequados a gêneros específicos. Não dependem, como o nosso anacronismo supõe, da psicologia do autor nem da sua maior ou menor representatividade empírica. Toda imagem, no caso, relaciona-se a um padrão lógico de desenvolvimento da argumentação, que implica o cálculo de seus efeitos ornados; o que se consegue, via de regra, alterando-se regradamente a isotopia semântica de outras imagens relacionadas, no sentido retoricamente consuetudinário da congruência de verba e verba, como adequação de verba e res, ou de imagem com imagem, como adequação de imagem e tópica da invenção. O procedimento binário - divisão dialética das tópicas dos argumentos/condensação metafórica dos temas e subtemas divididos - é sempre aplicado, conferindo aos discursos certa rigidez esquemática também na incongruência continuamente produzida, que pode causar desagrado à "liberdade livre", como dizia Murilo Mendes, da associação de idéias da concepção modernista e moderna de poesia.

É discutível, quando se consideram historicamente as representações desse tempo, que a produção de formas dinâmicas, curvas, serpentinadas, enrugadas, confusas, confundidas, enroladas, quebradas, dobradas, espelhadas, acumuladas, ornamentadas, antitéticas, opostas, contrapostas, hiperbolizadas, labirínticas, deformadas, anamorfóticas, alegóricas, claro-escuras, herméticas etc. seja necessariamente decorrência de qualquer espécie de irracionalismo, dilaceramento e angústia. É discutível que as artes do século xvII, principalmente as formuladas como variantes do estilo asiático, hoje muitas vezes tidas por "afetadas", como é o caso de Góngora e de seus inúmeros êmulos luso-brasileiros que figuram matérias humildes com estilo sublime quando imitam poetas neotéricos latinos e alexandrinos, sejam expressão de angústia dos indivíduos que as produziram ou que sejam naturalmente fúteis e pedantes. É discutível que, nos casos supostos em que os autores das representações quiseram representar paixões, eles o tenham feito expressivamente, sem a mediação de preceitos técnicos objetivamente partilhados. Discutibilíssimo é que tenham querido representar paixões individuais como idealistas alemães às voltas com a sublime organização burocrática da essência da cultura. As artes do século XVII conhecidas por "barrocas", "informais" e "irracionais" não são "irracionais", "informais" e "barrocas". Elas são versões neo-escolásticas do Livro III da Retórica e das novas conceituações de "dialética" e "retórica" feitas no século xvi em Roma, em Florença, na França, em Castela, quando se atribuiu à dialética a tarefa de definição e contra-definição das tópicas até entāo exclusivas da retórica, modificando-se esta como doutrina renovada da elocução ou do ornato dos temas e subtemas obtidos pela análise dialética das matérias. Todos os grandes tratados retórico-poéticos do século xvi que chegaram ao 
Brasil por meio, principalmente, da Companhia de Jesus, como Artificio y Arte de Ingenio, de Baltasar Gracián (1644), Il Cannocchiale Aristotelico, de Emanuele Tesauro (1654), Nova Arte de Conceitos, de Francisco Leitão Ferreira (1718), recorrem ao Organon e ao De anima, propondo as dez categorias e as especificações aristotélicas acerca do juízo silogístico como esquemas de definição e ordenação dialéticas dos temas e dos argumentos das representações; ao mesmo tempo, recuperam neo-escolasticamente a doutrina aristotélica da metáfora, feita no Livro III, da Retórica, e as leituras do mesmo feitas por Cícero e Quintiliano, para tratar da ornamentação das dez espécies de temas obtidos pela aplicação dialética das categorias às matérias das representações. Então, na Espanha, na Nova Espanha, no Peru, no reino de Nápoles, em Roma e em Portugal são correntes os tratados de autores gregos, transmitidos em suas versões bizantinas, como o de Longino, Sobre o sublime, e os de Demétrio Falereo, Dionísio de Halicarnasso e Hermógenes, sobre a elocução. Como demonstra uma das maiores especialistas em Quevedo, Luisa López Grigera, no século Xvil os usos desses autores gregos acrescentaram uma grande quantidade de distinções aos três estilos fundamentados em Cícero e Quintiliano correntes no século Xvi - alto, médio, baixo - constituindo os vários estilos das várias artes hoje classificadas e unificadas dedutivamente como "barrocas"17. Como artes regradas mimeticamente, aplicam verossímeis e decoros específicos dos gêneros e estilos, adaptando os efeitos às ocasiões da hierarquia como representação de afetos adequados à centralização do poder monárquico, como fica evidente em toda a obra de Vieira, na poesia chamada Gregório de Matos, nos textos históricos luso-brasileiros sobre as guerras holandesas ou na terrível versalhada das academias da primeira metade do século XVIII. Não conhecem a individuação expressiva do romantismo, pois operam com tipos, caracteres, ações e paixões precodificados de uma jurisprudência de imitação das autoridades dos vários gêneros, principalmente os latinos, Marcial, Pérsio, Lucano, Juvenal, Petrônio, Sêneca, que foram somados, no século xviI, aos autores imitados no xvi, Cícero, Horácio, Ovídio, Virgílio. Supondo-se por um momento a validade transistórica da noção romântica de "expressão", ou seja, supondo-se que os autores desse tempo tivessem querido representar paixões individuais "barrocamente" coisa vulgaríssima e sem arte sumamente indecorosa na sociedade corporativa luso-brasileira do século XV II, nunca o teriam feito sem aplicar formas do todo social objetivo, como formas coletivas de valor assimetricamente partilhado, à composição de tipos e caracteres sofrendo de paixões

17 Cf. GRIGERA, Luisa Lopez. Anotaciones de Quevedo a la Retórica de Aristóteles. Estudio preliminar, edición de las anotaciones de Quevedo a la Retórica de Aristóteles en versión paleográfica y moderna con notas. Salamanca: Universidad de Salamanca, 1998, p. 83.

Barroco, neobarroco e outras ruinas $r 23$ 
modelares. O que é entendido dedutivamente como "irracionalismo", "informalidade" e "angústia" do "barroco" é, enfim, racionalmente formalizado como efeito de informalidade de uma paixão qualquer, mas paixão qualquer sempre aristotelicamente regrada como o "excesso vicioso para menos", o "meio-termo virtuoso" e o "excesso vicioso para mais", da Ética a Nicômaco, que ordenam os elencos de tópicas imitadas neo-escolasticamente. As paixões estão na natureza, mas não são informais, quando paixões artisticamente representadas, pois sua codificação é retórica. ${ }^{18}$

O entendimento redutor da representação como adequação ao "real" pretotalizado ou expressão da "subjetividade psicológica" oblitera a formalidade de prática das representações coloniais. Tão reais como o tráfico negreiro, elas encontram o real de seu tempo como sistema regrado de prescrições retórico-poéticas e orientações teológico-políticas partilhadas assimetricamente por autores e públicos contemporâneos. Elas põem em cena não só as matérias, os temas e as interpretações deles tidas por verdadeiras e verossí-

18 Nos usos dedutivos de "barroco", a linguagem das representações nāo é definida como realidade efetiva de prática contemporânea de outras práticas discursivas e não-discursivas do século XVVII, mas avaliada segundo critérios que doutrinam as artes como representação transparente de conteúdos semânticos, totalização realista de conteúdos pretotalizados como "real" e expressão psicológica de unidades e identidades preformadas como "subjetividade liberal". Os juizos de gosto sobre as representações do século XVII formulados nesses usos opinam que são caracterizadas por "excesso", "artificialismo", "jogo de palavras", "afetação", "alambicamento", "mau-gosto", "acúmulo", "niilismo temático", compondo com as classificações a alienação delas como formalismo retórico dissociado do real do seu tempo, sem determinar documentalmente se tais classificações são historicamente aplicáveis aos objetos e se têm efetivamente tais funções e valores em seu tempo. Simultaneamente, como juízos de gosto, operam exclusōes hierarquizadoras, que constituem a autoridade do lugar institucional de sua enunciação como interesse que prescreve uma noçāo particular de clareza, um gosto particular e um conceito particular de arte como universais. Quando o idealismo descarta a mediação técnica, o positivismo recalcado retorna, afirmando por exemplo que a pintura de Rubens demonstra - espera-se sempre que favoravelmente - que as mulheres holandesas tinham celulite. Ou que o carnavalesco Joãozinho Trinta e a escola de samba Beija Flor são modelos para explicar historicamente os festejos coloniais. Ou produz o problema, que historicamente é pseudo-problema, de determinar a causa psicossocial de emoções angustiadas, pessimistas, ressentidas, irracionais, informais, artificiais, excessivas, deformadas, ociosas, vazias e pedantes supostamente expressas. Como no caso, paradigmático, da folclorização da poesia atribuída a Gregório de Matos e Guerra, que faz de conta não saber que não há nenhum exemplar autógrafo do poeta nem nenhum texto editado em vida por ele, quando aplica sistematicamente o método idealista por excelência, o biografismo psicologista, a discursos que chegaram ao presente sem nenhuma determinação de autoria, produzindo os Gregórios de Matos pau-pra-toda-obra de programas bairristas, nacionalistas e "pós-utópicos".

$24 \neg$ João Adolfo Hansen 
meis em seu tempo, mas também os procedimentos técnicos racionalmente aplicados para produzir os efeitos; com isso, compõem a compatibilidade entre as interpretações feitas pela enunciação e por personagens em ato e os atos de interpretação das recepções diferenciadas que conferem sentido e valor aos discursos ${ }^{19}$.

Ruínas do século XVII - algumas regras de intervenção O trabalho com as representações luso-brasileiras do século XvıI deve tratar a história historicamente e, para isso, evitar as invariantes transistóricas que fazem encontrar o Mesmo de um arquétipo em todos os tempos. É a especificidade histórica das práticas de representação do século Xvil que me interessa, ou seja, a especificidade de seus condicionamentos materiais e institucionais, de seus códigos lingüísticos e bibliográficos, de seus padrōes retórico-poéticos e de suas doutrinas teológico-políticas. O trabalho de reconstrução arqueológica da particularidade da representação colonial não é uma atividade meramente antiquária, no sentido arcaizante e regressivo do termo "antiquário" usado em algum lugar por Nietzsche para ironizar um tipo de historiador que coleciona velharias perdendo a perspectiva do futuro ${ }^{20}$. O passado está felizmente morto e seus restos só interessam no presente como material para um trabalho de destruição de universalismos que descartam sua historicidade. Os mortos só interessam na crítica dos vivos e dos muito vivos.

Quando se dissolve a naturalidade das apropriaçōes dedutivas das representaçōes coloniais, elas tornam-se matéria com que se produz, no presente da operaçāo, um resultado verossímil que as identifica como práticas datadas. E, enquanto práticas, como usos regrados, particulares e interessados de transformação de matérias, que naturalizavam os efeitos produzidos em seu tempo reproduzindo a hierarquia. O trabalho com as repre-

19 Cf. CARTIER, Roger. George Dandin ou le social en représentation. Annales. Littérature et histoire (Paris), Armand

Colin, p. 283, (49e année, n. 2), mars-avr.

20 A reconstituiçāo das representaçōes do século XVII nāo é "historicista", como propôs Haroldo de Campos, pois nāo pressupōe as leis históricas necessárias do etapismo da "factualidade literária". Mas ela se quer histórica e não "pós-utópica". Também não é "formalista", como sentenciam os amigos de Lukács. Mas se quer formal, pois a reconstituição da formalidade das práticas do século XVll evidencia as funçōes e os valores da representação em seu tempo, permitindo construir uma diferença útil também para evidenciar a particularidade de usos normativos de Lukács em cursos de secretariado e letras. E nāo é "retoricista", porque nāo reduz as formas poéticas ao procedimento técnico. Mas trata de retórica porque historicamente é a instituição que ordena todas as representaçōes do século XVII, demonstrando justamente que, sendo retóricas, nāo sāo nem podem ser "barrocas" e "neobarrocas", ou seja, caudatárias do idealismo alemāo e da pós-utopia

Barroco, neobarroco e outras ruinas -25 
sentações do século XVII é polêmico, definindo-se como um interesse político situado no campo dos estudos literários que pressupõe escolhas parciais e limitadas, condicionadas pelo seu lugar institucional, a Universidade que se conhece,21 para abrir o campo de sua atividade, deslocando-se por fora de toda homogeneização apriorística. Por isso mesmo, o trabalho também implica, programaticamente, a perda de várias possibilidades. teóricas e institucionais, pois só se sustenta naquilo que faz, ou seja, como prática particular e interessada em produzir novos instrumentos de análise do passado que tenham eficácia crítica como intervenção no presente. ${ }^{22}$ Não é "mais verdadeira" nem "verdadeira", mas outra. Propondo-se a fazer uma história descritiva das representações coloniais, pressupõe que as apropriações do presente que não consideram a sua formalização normativa inicial têm sua capacidade de explicação histórica reduzida e comprometida pela universalização da sua particularidade.

As representações coloniais constituem seus públicos retoricamente como tipos hierarquizados que devem ser persuadidos acerca do que é figurado nelas. Como só é possível persuadir e ser persuadido a respeito daquilo que se conhece, elas evidenciam-se como discursos que reproduzem padrões do todo social objetivo, encenando os modelos institucionais que regulam uma experiência coletiva partilhada assimetricamente segundo as diversas posições dos autores, dos sujeitos de enunciação, dos destinatários e dos públicos empíricos na hierarquia dos privilégios. Em todos os casos, as representações reproduzem, na situação particular de sua ocorrência, uma jurisprudência dos signos partilhada coletivamente como memória social de "bons usos" Evidentemente, não são padrões iluministas, românticos, modernos ou pós-modernos, pois não há autonomia autoral, nem autonomia estética, além de "público" não ser a "opinião pública" teoricamente dotada de autonomia política, representatividade democrática e livre-iniciativa crí-

21 É estratégico lembrar o que dizia David Perkins: "Em geral se explica este revival (o interesse teórico pela contextualização histórica) por uma razão que em si é contextual: os estudantes dos anos sessenta são os professores dos oitenta, não tendo perdido completamente as motivaçōes políticas da sua juventude. Eles destacam as relações entre as realidades sociais e a literatura, porque a sociedade permanece como objeto privilegiado de investigação. Como ldeologiekritik, seus estudos se engajam nas questōes políticas contemporâneas, mesmo quando o tema tratado se constitui de discursos produzidos no passado. Negar o envolvimento do conflito social e das relaçōes de poder com os textos críticos e literários tornaria a profissão irrelevante". Cf. PERkINS, David. História literária; um panorama (Trad. João Cezar de Castro Rocha). Cadernos do mestrado/literatura (Rio de Janeiro), Depto. de Letras, UERs, p. 9, 1993.

22 Um trabalho semelhante a este vem sendo desenvolvido com muita eficácia pelo Prof. Antônio Alcir Bernárdez Pécora, do Instituto de Estudos da Linguagem da Unicamp.

$26 \neg$ João Adolfo Hansen 
tica, mas um testemunho da representação incluído pela representação como representação. ${ }^{23}$ É útil lembrar o que escreve Fernando Novais: “(...) não podemos fazer a história desse período como se os protagonistas que a viveram soubessem que a Colônia iria se constituir, no século xıX, em um Estado Nacional"24.

Regras de reconstrução. Leituras e códigos lingüísticos Os estudos brasileiros das representações coloniais costumam aplicar-lhes a legibilidade específica da literatura densamente letrada da modernidade pós-vanguarda. O padrão é modelado pelos esquemas que organizam a percepção do texto impresso e implica critérios de orientação temporal, estética, ideológica, profissional e institucional do sentido, como "racionalização negativa da forma" "ruptura estética", "originalidade", "utopia política", "progresso", "subjetividade psicológica” "crítica", "autoria”, "plágio" "analfabetismo", "mercado" "direitos autorais" e outros. Eles se demonstram exteriores, quando aplicados retrospectivamente a representações ordenadas por outras categorias de pensamento e prescrições técnicas, veiculadas por outros suportes e meios, visando outros fins e lidas, vistas, oralizadas e ouvidas por outros públicos, conforme outros sentidos históricos, institucionais e informais, dados à experiência do tempo.

Quando se determina historicamente a representação colonial, ficam evidentes nela as técnicas retóricas aplicadas como racionalidade não-psicológica que figura os efeitos de sentido para a recepção segundo orientações pragmáticas diversas. Os estilos das representações formalizam posições hierárquicas a partir das quais os efeitos se tornam adequados aos temas tratados e circunstâncias contemporâneas do seu consumo, podendose afirmar que o decoro retórico-poético que as regula também é decoro ético-político que ordena as posições hierárquicas representadas e suas recepções. No seu estudo, as categorias de prática, representação e apropriação têm valor heurístico, pois permitem desnaturalizar as representações, deslocando-as da generalidade dedutiva de "barroco" e transistórica de "neobarroco". Prática, apropriação e representação são categorias pertinentes pois, permitindo reconstruir materialmente a particularidade das letras coloniais, também permitem criticar interpretações que as (des)qualificam porque (não) se adaptam à teleologia organicista de seu programa estético-político que concebe as formas passadas de maneira unilateral, por considerá-las como etapas para si mesmas. Permitem também a crítica de interpretações "pós-utópicas", que fazem equivaler indistinta-

23 Cf. MERLIN, Hélène. Public et Littérature en France au XVIle siècle. Paris: Les Belles Lettres, 1994, p. 30.

24 NOVAIS, Fernando. "Condiçōes de privacidade na Colônia". In: História da vida privada no Brasil: cotidiano e vida privada na América Portuguesa. São Paulo: Companhia das Letras, 1998, p. 1;

Barroco, neobarroco e outras ruinas $\ulcorner 27$ 
mente procedimentos de leitura de poesia, que necessariamente não dependem de nenhum pressuposto historiográfico, procedimentos artísticos de transformação sincrônica dos restos coloniais como "neobarroco" e procedimentos críticos e historiográficos, que aplicam transistoricamente a noção de "barroco", para, classificando-se a si mesmos como "neobarrocos", classificar os restos coloniais como "barroco histórico" Uma história descritiva das representações coloniais é uma história de todas as leituras possíveis de um texto colonial determinado, que tenta reconstruir as condições técnicas, materiais e institucionais sob as quais várias significações são geradas por leitores cujas disposições receptivas possuem diferentes mediações históricas e sociais 25 . A descrição pressupõe o arbitrário, ou seja, a não-naturalidade dos usos do passado; como descrição, não é "neutra", pois é obviamente limitada e particular. É útil, para fazê-la, reconstituir a hipotética primeira normatividade das representações, ou seja, a hipotética primeira inteligibilidade normativa dos seus códigos lingüísticos e bibliográficos composta em seu tempo como legibilidade ou oralidade, cujo conhecimento permitiria excluir significações não-previstas na sua invenção, como "barroco", para também especificar a historicidade das leituras delas feitas segundo os esquemas dedutivos "barroco" e "neobarroco". É básico, neste sentido, descrever os preceitos técnicos dos códigos lingüísticos ou retórico-poéticos, como gêneros, formas e estilos aplicados às representações, na medida em que, trate-se de um poema ou de uma ata de Câmara, os gêneros são protocolos que classificam e hierarquizam as matérias tratadas segundo usos particulares, oficiais e nãooficiais, tornando-as adequadas a destinatários específicos compostos como "leitores implícitos" na variação estilística da forma. A formalização das regras dos vários gêneros impede, quando se considera sua mediação, que se tome o discurso como transparência dando acesso direto a um "real" pretotalizado. O trabalho define o discurso como prática, propondo que a reconstituição das regras que o formalizam pode impedir, por exemplo, que um discurso deliberativo produzido em circunstância oficial seja lido univocamente, ou que uma desqualificação epidítica formulada em circunstância polêmica seja tomada como informação verdadeira.

25 GUMBRECHT, Hans Ulrich. "Consequences of an Aesthetics of Reception". In: Making sense in life and literature. Minneapolis: University of Minnesota Press, 1992. Uma história descritiva deve supor, como propõe Gumbrecht, que "(..) uma das primeiras tarefas importantes da crítica literária deveria ser a reconstrução dos propósitos aos quais leitores históricos aplicaram suas ações de entendimento de significaçōes textuais objetivas e subjetivas - por outras palavras, o estudo da história do seu interesse literário. (...) Uma fenomenologia da leitura deveria também explicar a conexāo entre o nível de entendimento como ação social e os atos comunicativos (perceptivos)que o constituem". Idem, p. 23.

$28 \neg$ Joāo Adolfo Hansen 
É possível recompor as estruturas retórico-poéticas e teológico-políticas das representações a partir de usos, definindo-se "uso" como prática historicamente condicionada de transformação de matérias tradicionais, como os modelos retóricos antigos e os preceitos doutrinários aristotélicos, neoplatônicos, estóicos, patrísticos, escolásticos e neoescolásticos da teologia-política ibérica, e de matérias locais, um referencial discursivo, como a murmuração informal documentada por vários agentes contemporâneos, e os documentos formais das instituiçōes. Os resíduos coloniais são fragmentos de usos que chegaram ao presente transformados nas apropriações que lhes conferiram as formas e os modos como hoje são editados e lidos. Como toda prática é por definição regrada, os resíduos de usos coloniais permitem especificar as regras de estruturas diversas de que eles mesmos são variações como transformações situadas e posicionadas. Em todos os casos, a reconstituição dos padrões retórico-teológico-políticos do século XVII prevê três procedimentos, à maneira dẹ Bakhtin/Voloshinov. Pelo primeiro deles, não se separa o conteúdo da representação da realidade material do signo. Pelo segundo, não se isola o signo das formas concretas da sua comunicação social. Pelo terceiro, não se isola a comunicação e suas formas das práticas das quais elas são contemporâneas.

Para estabelecer a normatividade das representações em seu tempo, a quantificação, a seriação e o cruzamento de vários regimes discursivos luso-brasileiros, espanhóis, italianos e outros - por exemplo, pragmáticas de trajes, precedências e tratamentos, bandos, ordens-régias, regimentos de governadores, livros de aconselhamento de príncipe, livros de alfândegas, livros de emblemas, atas e cartas de Câmaras, narrativas de festejos públicos comemorativos, decretos conciliares e bulas, tratados de teologia e direito, preceptivas retóricas, documentos da censura inquisitorial, crônicas, correspondência, poemas, sermões, programas de ensino de ordens religiosas, o Ratio studiorum, livros, manuscritos, bibliotecas, artes de morrer etc. - permitem estabelecer, na diversidade das situações dos usos particulares, homologias estruturais e formais, cujas unidades especificam prescrições, funções e valores encenados. As homologias permitem formalizar os sistemas retórico-poéticos e teológico-políticos na base da invenção. Especificando-se as homologias pela mediação de documentos, é possível recompor a normatividade de regimes discursivos que, pondo em cena os pressupostos doutrinários da teologia-política ibérica, apropriam-se de modelos retórico-poéticos aristotélicos e latinos para adaptálos neo-escolasticamente, segundo orientações específicas da "política católica" da Coroa, em formas locais, orais e escritas, manuscritas e impressas de sua invenção, publicação, circulação e consumo. As homologias também permitem evidenciar os condicionamentos sócio-políticos da sua destinação utilitária em várias circunstâncias da hierarquia e, ainda, de seus usos particulares por públicos empíricos contemporâneos.

Barroco, neobarroco e outras ruínas -29 
Relacionando os modelos reconstruídos com os condicionamentos materiais e institucionais contemporâneos, investigáveis diretamente em documentos de práticas discursivas e indiretamente em documentos de práticas não-discursivas, o trabalho propõe a especificidade histórica deles como uma diferença histórica verossímil, ou seja, como uma diferença histórica construída que tem seu alcance explicativo condicionado pela documentação e, obviamente, pela particularidade da pesquisa feita em um lugar institucional devastado, a Universidade neoliberal.

É razoavelmente simples recompor descritivamente as cadeias das apropriações de representações coloniais realizadas a partir dos programas do Instituto Histórico e Geográfico Brasileiro, no século xIx, em que coexistiram duas concepções de história, de um lado a antiga concepção ciceroniana da mesma como mestra da vida, herdeira da Ilustração católica portuguesa, e, doutro, o projeto romântico, moderno no século xIX, de escrever a gênese da nação ${ }^{26}$, para evidenciar a particularidade dos usos delas nos termos da "invenção das tradições", de Hobsbawm, como invençāo de baianidades, mineiridades, pernambucanidades, nacionalidades e mais essências.

Uma história descritiva das apropriações de representações coloniais realizadas por agentes empíricos coloniais é, no entanto, quase sempre imediatamente limitada pelo vazio dos arquivos, tendo-se que recorrer mediatamente a informações fornecidas pela mediação normativa de letrados coloniais, que indiciam as apropriações normativas e também não-normativas das representações na oralidade e na leitura. Por outras palavras, como a documentação sobre os públicos coloniais empíricos é escassa, é a descrição da normatividade retórica do contrato enunciativo dos vários gêneros, que especifica os modos institucionais como são representados sujeitos de enunciação, temas e destinatários, que é útil, num primeiro momento, para estabelecer a especificidade simbólica de modos históricos de representar. No caso das letras, a consideração da estrutura performativa da enunciação dos discursos permite particularizar as normas do gênero adaptado à circunstância de figuração de determinado tema, constituindo o destinatário como o "leitor implícito" de Iser. O destinatário recebe a representação do tema e, simultaneamente, os critérios avaliativos dos atos de fala representados nela, como um ponto de vista ou perspectiva a partir da qual o efeito é recebido adequadamente. A destinação utilitária das representações evidencia que obedecem a programas específicos das instituições portuguesas, que as condicionam ou efetivamente determinam, caso da censura inquisitorial. A correspondência jesuítica, a oratória sacra, os diálogos, os tratados

26 GUIMARÃES, Manoel Luís Salgado. Nação e civilização nos trópicos: o Instituto Histórico e Geográfico Brasileiro e o projeto de uma história nacional. Estudos Históricos / (Rio de Janeiro), FGV, p. 8, 1988.

$30 \neg$ João Adolfo Hansen 
descritivos, a poesia encomiástica e satírica são alguns desses gêneros tipicamente utilitários. Nesse sentido, tanto os sujeitos de enunciação quanto os destinatários de vários gêneros aparecem formalizados como tipos hierárquicos, que emitem e recebem discursos polêmicos e cerimoniais, visando a produzir efeitos adequados a fins particulares da colonização. Sendo representaçōes de práticas, os resíduos coloniais aparecem ordenados por esquemas culturais cuja estrutura pode ser deduzida a partir dos usos diferenciados de referências comuns encenadas neles, podendo-se, por comparação, também especificar o caráter diferencial das auto-representações dos agentes históricos dos usos como apropriações diferenciadas em situação. Pressupondo-se que em seu tempo os resíduos existiam plenamente através de sistemas de representação, não se pode fazer a história das práticas que os produziram utilizando simplesmente as representações delas nos textos. É preciso também construir uma história das regras retórico-poéticas de sua produção textual e iconográfica ${ }^{27}$, como prescrições, técnicas, padrões, esquemas, modelos, além dos modos de sua divulgação, circulação e uso.

Regras de reconstrução. Leituras e códigos bibliográficos Além dos códigos lingüísticos ou retórico-poéticos, é básico reconstruir os códigos bibliográficos, lembrando que, na sua forma normativa inicial, grande parte das letras coloniais eram publicadas como manuscritos, sendo realizadas como "obras" somente quando eram oralizadas em circunstâncias oficiais, cerimoniais, polêmicas e informais ${ }^{28}$. Veja-se um exemplo. Em 1987, escrevi uma tese sobre a sátira atribưída a Gregório de Matos Guerra, trabalhando com a edição das obras atribuídas ao poeta feita por James Amado, em 196829, que repro-

27 CHARTIER, Roger. "Historia y prácticas culturales". Entrevista a Roger Chartier por Noemi Goldman y Leonor Arfuch. Entrepasados. Revista de Historia (Buenos Aires), El Libro, año Iv, n. 7, p. 140, 1994.

28 A respeito de códigos bibliográficos, é útil lembrar os trabalhos de CHARTIER, Roger. Publishing drama in early modern Europe. The Panizzi Lectures 1998. London: The British Library, 1999; DIAZ, José Simon. "El problema de los impresos literarios perdidos del Siglo de Oro". In: Edad de Oro, 2. Madrid: Universidad Autónoma de Madrid, 1983; LOVE, Harold. The culture and commerce of texts. Scribal Publication in Seventeenth Century England. University of Massachussetts Press, 1998; MCKENZIE, D.F. Bibliography and the sociology of texts. London: The British Library, 1986; HÉBRARD, Jean. "Des écritures exemplaires: I'art du maitre écrivain en France entre XVle et XVIIIe siècles". In: Mélanges de l'École Française de Rome, 107, 2, 1995; MCGANN, Jerome J. The textual condition. Princeton University Press, 1991; ZUMTHOR, Paul. "Intertextualité et mouvance". Littérature, 41, 1981; Essai de poétique médiévale. Paris: Seuil, 1972; A letra e a voz. A "Literatura" Medieval. São Paulo: Companhia das Letras, 1993.

29 Cf. AMADO, James e PARANHOS, Maria Conceiçāo (Org.). Obras completas de Gregório de Mattos. Crônica do viver baiano seiscentista. Salvador: Janaina, 1968, $7 \mathrm{~V}$.

Barroco, neobarroco e outras ruínas $\sim 31$ 
duz o Códice Rabelo da Biblioteca Nacional do Rio de Janeiro30. O exame deste códice é importante no que se refere aos códigos bibliográficos, devido principalmente às didascálias escritas no alto das páginas, antes de cada poema, que informam sobre circunstâncias da composição das sátiras, pessoas visadas, maneiras como circulavam e, principalmente, modos contemporâneos de fazer, definir e consumir poesia. Por exemplo, as didascálias informam que, entre 1680 e 1700, os poetas de Salvador se reuniam nas tardes de sábado na Quinta do Tanque, chácara onde os jesuítas aclimatavam plantas da Ásia e da África, entregando-se a concursos de improvisação poética feitos muita vez segundo o modelo medieval do "mote e glosa" Os poemas que desenvolvem motes propostos para a improvisação oral são compostos com versos redondilhos, geralmente, cujas rimas, impostas por regras de decoro e verossimilhança, eram dadas previamente como esquema para ordenar os temas, como as rimas do gênero cômico "apa, epa, ipa, opa, upa" ou "acha, echa, icha, ocha, ucha". As agudezas evidenciavam o engenho e a perícia técnica dos autores, sendo aplaudidas como signos de discrição. Os poemas oralizados nessa e em outras circunstâncias formais e informais de Salvador eram, muitas vezes, transcritos em folhas avulsas; outras, memorizados, sendo copiados em novas folhas ou reproduzidos na oralidade, produzindo-se variantes transcritas, por sua vez, em outras folhas avulsas ou novamente reproduzidas por novos agentes na oralidade. Era hábito colecioná-los em cadernos, com o nome "Papéis vários", cujas folhas às vezes recebiam ilustrações. As didascálias evidenciam os protocolos de leitura aplicados à ordenação dos poemas no códice, segundo a hierarquia então corrente dos gêneros poéticos, permitindo reconstruir as prescrições aplicadas ao contrato enunciativo, ou seja, à representação de sujeitos de enunciação e destinatários nos poemas. Eles são dispostos no códice como grupos classificados por gêneros, ou seja, a própria disposição deles evidencia a aplicação de princípios retórico-poéticos que informam sobre maneiras contemporâneas de definir, hierarquizar, produzir e apreciar as belas letras.

Os quatro volumes do Códice Rabelo e os outros da tradição Gregório de Matos são centrais, por isso, na especificação do estatuto contemporâneo de autor e autoria dos poemas. Generosamente, Antônio Houaiss propôs que se fizessem cópias de todos os manuscritos contendo poesias atribuídas a Gregório de Matos para distribuí-las a várias instituições de pesquisa e pesquisadores brasileiros que, organizados em equipes, um dia talvez poderiam vir a estabelecer um "resíduo irredutível" a ser atribuído com certeza ao poeta. A inexistência de autógrafos, contudo, e o fato de Gregório de Matos nada ter editado em vida tornam a proposta inviável. A questão da autoria dos poemas é radicalmente alterada, porém, quando se examina a materialidade mesma dos códices. 
No Códice Rabelo, a dispositio dos poemas superpõe duas ordenações distintas. A primeira é cronológica, feita segundo etapas da vida do personagem Gregório de Matos, tal como é figurado na Vida do excelente poeta lírico, o doutor Gregório de Mattos Guerra, a biografia de gênero prosopográfico composta pelo licenciado Manuel Pereira Rabelo, que utilizou, para escrevê-la, tópicas dos poemas que coletou e atribuiu ao poeta: Portugal (1648-1682(6?), Bahia (1682(6?)-1694), Angola (1694-1695), Recife (1695-1696). A segunda ordenação, retórico-poética, é mais interessante, no sentido da materialidade referida, pois dispõe os poemas segundo uma hierarquia de gêneros: primeiro a poesia lírica (antes a sacra, depois a amorosa), em seguida a poesia satírica, nas duas variantes aristotélicas do cômico, ridículo e maledicência. Sem negligenciar uma hierarquia das formas: em primeiro lugar, as italianas, como o soneto, ou as que usam da medida nova; em seguida, as formas mais populares ou mais arcaicas, como os romances de medida velha e, entre eles, oitavas, décimas, silvas. Com exceção da edição de James Amado, as antologias dessa poesia geralmente não consideram a ordem dos poemas nos manuscritos; assim, quando são publicados hoje, na forma que conhecemos, a letra impressa que os transforma em textos legíveis, eles também são transformados ou autonomizados como objetos de contemplação estética. Não é o que acontece nos manuscritos, porém, pois é o contexto do códice que lhes dá sentido, em seu tempo, como elementos de um conjunto dialógico, uma espécie de polílogo intertextual, característico de sua improvisação ou declamação oral, que a disposição deles nos manuscritos reproduz. Evidentemente, a fixação e a impressão deles como textos para serem lidos como objetos esteticamente autônomos destrói a mobilidade inicial inerente a eles, que só existe em suas variações. Obviamente, esse é o modo como hoje se lê poesia. Mas uma história literária descritiva não poderia ignorar essa primeira normatividade material dos poemas para evitar juízos transistóricos. Por exemplo, quando eles são publicados hoje, a pontuação moderna, que distribui as funções sintáticas lógica e impessoalmente, põe de lado a pontuação retórica que era específica da representção da actio da fala como recitação e declamação dos poemas na oralidade. Por isso, a reconstrução dos códigos bibliográficos pode impedir que os manuscritos coloniais sejam entendidos como simples suportes neutros e invariáveis. Ela também pode evitar a formulação de pseudo-problemas críticos, como o que é posto por leituras que generalizam a concepção romântica de poesia como expressão, psicologizando os poemas, quando perguntam como foi possível que um mesmo homem tenha escrito poemas líricos de tamanha elevação ao lado de tantas obscenidades satíricas.

Quando os códices manuscritos são examinados, evidencia-se que neles a função-autor é o ponto de convergência das diversas versões de poemas que realizam a auctoritas do

Barroco, neobarroco e outras ruínas - 33 
gênero retórico-poético do qual eles eram, para quem os juntou em códices nos séculos XVII e XVIII, outras aplicações. A autoria aparece, nos códices, não como realidade psicológica, mas como dispositivo discursivo. Ela decorre da aplicação de esquemas táticos, retóricos, pressupostos pela recepção contemporânea, ao menos pela recepção contemporânea letrada, que produzia e lia os manuscritos. No século XVII, ouvintes e leitores discretos também julgavam a arte com que as regras do dispositivo eram aplicadas, ao mesmo tempo que apreciavam a significação dos temas tratados. Desta maneira, no Códice Rabelo, a disposição dos poemas permite fazer do nome do poeta Gregório de Matos um dispositivo de designação de uma auctoritas lírica (sacra e profana) e também de uma auctoritas satírica (ridícula e maledicente). No caso, a autoria tem função classificatória, antes de funcionar como confirmação da origem dos poemas. Nesta perspectiva, Rabelo pôde coletar textos de fontes diferentes: por exemplo, paródias macarrônicas, que os estudantes de Coimbra faziam da poesia de Camões, que atribuiu a Gregório, ou trechos de poemas espanhóis, provavelmente de Lope de Vega, porque para ele o nome era antes um gênero que um autor individualizado. Reunindo sob a etiqueta Gregório de Matos todos os poemas que afirma ter coletado na oralidade e em folhas volantes, Rabelo constitui uma autoridade lírica e uma autoridade satírica. Já se disse que ele se enganou, em suas escolhas, quanto à origem dos poemas; mas o seu critério não era o de origem. Para Rabelo, a autoria dos poemas decorre da aplicação do conceito latino de fides, que se pode achar em Quintiliano, quando trata da elegia erótica de Ovídio, distinguindo-a dos poemas de Galo, Tibulo e Catulo. A diferença entre os estilos deles não é psicológica, pois não decorre de suposta psicologia do homem Publius Ovidius Naso, mas consiste na maneira técnica como o poeta Ovídio regula a aplicação de tropos e figuras a tópicas da elegia erótica imitadas por todos os poetas romanos que se especializam no gênero. Ovídio é lascivo, Galo mais duro e Catulo, erudito. Todos são elegíacos, assemelhando-se na maneira de aplicar os lugares-comuns e utilizar o mesmo verso prescrito para o gênero. A diferença deles reside na variação elocutiva, ou seja, no intervalo de aplicação de tropos e figuras aos lugares-comuns que todos eles aplicam, e seu público sabe disso, podendo dizer Ovidius lascivus. Rabelo não ignorava que muitos poemas de seu manuscrito eram de poetas bastante conhecidos no século XviI, como Tomás Pinto Brandão, que viera de Portugal para a Bahia acompanhando Gregório de Matos, ou Francisco Rodrigues Lobo, D. Francisco Manuel de Melo, Lope de Vega etc. Mas ele os enfeixa na sua taxonomia, conservando o nome de Gregório de Matos para nomear o conjunto, uma vez que este representa, para ele, a excelência mesma do gênero que o manuscrito ilustra. Desta maneira, considerar a auctoritas tal como composta nos códices manuscritos significa também considerar o público e a obra. O protocolo de leitura do manuscrito obriga 
que se trate a dispositio dos poemas como evidente para aqueles que deviam assegurar sua recepção. No caso, dois tipos de destinatários devem ser lembrados, o discreto e o vulgar, definidos em Portugal e na Espanha, nos séculos XVII e XVIII, por critérios éticos, teológico-políticos e retórico-poéticos.

O destinatário discreto é figurado como capacidade de ajuizar a aptidão técnica da forma poética, valorizando o artifício aplicado. Ou seja, o discreto é o tipo caracterizado pelo engenho retórico e pela prudência política típicos da racionalidade de Corte divulgada institucionalmente, no Estado do Brasil, no ensino organizado a partir de 1599 pelos modelos do Ratio studiorum da Companhia de Jesus. Segundo Inácio de Loyola, a discretio não é diferente da caritas, pois é a capacidade de fazer juízos justos e prudentes. $O$ tipo discreto é erudito e domina as artes da memória que lhe permitem conhecer todos os lugares-comuns aplicados aos poemas. Por isso, testemunha a força do sistema de regras, que conhece e reconhece, como um equivalente direto ou um sinônimo da auctoritas figurada nos poemas. O Licenciado Rabelo é um discreto, pois coleciona e transcreve poemas para leitores que são como ele. Por oposição, o destinatário vulgar só recebe os efeitos pois, figurado como ignorante do preceito técnico que os produz, é constituído negativamente pelo manuscrito como incapaz de lê-lo, ou seja, de fazer as distinçōes dos agrupamentos da sua dispositio. Isso não significa que, segundo as prescrições do século XVII, os vulgares sejam insensíveis à poesia coletada. Podem ser afetados por ela e reagir a seus efeitos, mas não conhecem ou não compreendem o artifício ou as regras que presidiram sua invenção. Deve-se considerar que a representação dos "melhores" de então, feita sempre segundo esses critérios, era objeto de apropriações que a imitavam, emulavam e deformavam continuamente em várias situações, nas quais a hierarquia era rompida para logo se recompor. O que se evidencia, por exemplo, no ímpeto legisferante do tempo, cujas infindáveis pragmáticas de cortesias, precedências, formas de tratamento e trajes demonstram o empenho de controlar o desempenho adequado das aparências. Propostas como "política perfeição" ou meio para a representação de toda circunstância, as agudezas dos discretos do Códice Rabelo eram objeto de várias apropriações. Elas eram aptas, por exemplo, para produzir discursos aparentemente não-agudos, aparentemente informais, aparentemente sem proporção, como se não necessitassem das prescrições retóricas, para serem fruídos por vulgares. Nas discussões espanholas da tragicomédia, acusada pelos críticos tradicionalistas, os "terensiarcos" e "plautistas", de misturar gêneros e estilos de modo inverossímil, Lope de Vega responde às críticas:

\footnotetext{
...e escrevo com a arte que inventaram

os que o vulgar aplauso pretenderam,
}

Barroco, neobarroco e outras ruínas -35 
porque, como as paga o vulgo, é justo

falar-lhe como néscio para dar-lhe gosto ${ }^{31}$.

Nas letras luso-brasileiras coloniais, esta também é uma das principais representações do discreto: um tipo capaz de se fazer passar por vulgar, quando se dirige a vulgares, fingindo discreta e agudamente a vulgaridade da falta de discriçāo e agudeza. Em um mundo pautado pela representação, representa-se sempre o tema da dissimulação: entre vulgares, pergunta-se o personagem de um poema atribuído a Gregório de Matos, o discreto é discreto ou já é vulgar, conforme o julgamento dos vulgares, que é estúpido e nenhum? Uma das décimas afirma:

Dei por besta em mais valer,

um me serve, outro me presta;

não sou eu de todo besta,

pois tratei de o parecer32.

Os versos parecem glosar a prudência de Saavedra Fajardo:"Necia seria la ingenuidad que descubriese el corazón, y peligroso el imperio sin recato. Decir siempre la verdad seria peligrosa sencillez, siendo el silencio el principal instrumento de reinar" 33 .

Pode-se compreender, assim, porque é possível equivocar-se, quando os poemas inicialmente manuscritos e dispostos na ordem retórica do códice por Rabelo são lidos da mesma maneira como se trata um texto impresso. Quando percebidos por meio dos critérios relacionados à literatura impressa, os poemas satíricos atribuídos a Gregório de Matos parecem mal escritos e grosseiros, como se fossem rascunhos apressados. A crítica brasileira às vezes os considerou um gênero inferior, propondo que a lírica atribuída ao poeta é melhor, pois os poemas sacros e amorosos parecem mais acabados. Voltando ao manuscrito e tratando os poemas satíricos como textos manuscritos, fica evidente que aplicam diretamente o princípio do ut pictura poesis horaciano, que prescreve a clareza específica de cada gênero, o número de vezes que a peça deve ser ouvida e lida e o ponto de vista ou

31 LOPE DE VEGA. "Arte nuevo de hacer comédias en este tiempo (1609)", vs. 44-8. In: ESCRIBANO, F.S. e MAYO, A.B. Preceptiva dramática española (Del Renacimiento y el Barroco). Madrid: Gredos, 1965, p. 152.

32 mattos, Gregório de. Obras completas de Gregório de Mattos. Crônica do viver baiano seiscentista. (Ed. James Amado). Salvador: Janaína, 1968, 7 V., vol. II, p. 449.

33 SAAVEDRA FAJARDO, Diego. "Ut Sciat Regnare. Empresa 46". In: Empresas politicas: idea de un principe politicocristiano. (Ed. Quintin Aldea Vaquero). Madrid: Ed. Nacional, 1976, 2 V., vol. I, p. 406. 
a distância adequada da sua observação pelo destinatário, reproduzindo, no caso, a movência ou a circulação das variantes orais. A sátira, como se sabe, é um gênero público e, por isso, uma arte cenográfica, que deve ser oralizada teatralmente em voz alta para vulgares numa praça. Ela deve ser composta rapidamente, sendo para a poesia o que a caricatura é para o desenho: se for trabalhada como um soneto lírico, por exemplo, será obscura para vulgares incapazes de apreciar o estilo alto. Além disso, sendo oralizada, é dita uma só vez, pois perde o impacto agressivo se repetida. Quanto mais "grosseira" ela é, nos vários sentidos do termo, melhor funciona, pois sua grosseria está diretamente adequada ao seu modo público e oral de recepção. Quando a crítica não considera a função prescritiva das didascálias no códice e lê os poemas apenas na sua forma impressa, que obviamente é a nossa forma contemporânea de ler poesia, a sátira é retirada de seu contexto dialógico inicial e aparece imediatamente como mal escrita. O manuscrito, com o dispositivo que aciona, permite saber que ela deve ser ouvida e vista de longe, como em uma assembléia movimentada e ruidosa, uma única vez, com uma clareza absoluta, que é a clareza da obscenidade. Assim, os autores das sátiras que circularam na Bahia no século xVII, entre eles Gregório de Matos, calculavam no estilo a exata posição do destinatário, para que recebesse adequadamente os efeitos. Muito perto ou muito longe, não mais compreende, ou seja, a sátira decorre de um cálculo cenográfico preciso. Sua "grosseria", em todos os sentidos, resulta de uma técnica retórica racionalmente aplicada, não da expressão de uma psicopatologia qualquer. $O$ destinatário deve receber seu efeito como se não houvesse nenhum artifício em jogo. $O$ vulgar seiscentista a recebe como coisa natural, mas o discreto a percebe como totalmente artificial, ou seja, como efeito de um cálculo preciso da verossimilhança e do decoro estilísticos que finge a inépcia técnica das paixões grosseiras com total aptidão. Como dizem os preceptistas do século xviI, um pintor que faz um focinho torto não peca contra a arte, se a deformação estiver subordinada ao fim prescrito pelo gênero. Nos manuscritos, a movência dos poemas permite esclarecer essas significações de sua primeira normatividade, que é básico considerar quando se faz uma história descritiva deles.

A oposição discreto/vulgar, que formaliza os destinatários e regula as recepções coloniais das representações, não recobre as oposições jurídico-político-econômicas senhor/homem pobre livre/escravo ou fidalgo/plebe. A vulgaridade não é exclusividade dos "melhores" caracterizados pela propriedade e posição, nem da "população" do terceiro estado, os oficiais mecânicos e a "gente baixa", mas caracteriza todo e qualquer rústico falho de discernimento. Por oposição, é discreta a representação que se caracteriza pela racionalidade engenhosa e pela prudência ético-política, independentemente da posição estamental. A auctoritas e sua posse são um dispositivo de representação, ou seja, um dispositivo de 
produção da presença de uma posição hierárquica retoricamente regrada segundo a teologia-política do pacto de sujeição que define os privilégios dos súditos. Em inúmeras oca siões do século XVII, os termos da oposição discreto/vulgar são aplicados polemicamente nas representações, para classificar e hierarquizar pessoas, conferindo e negando posição ao sujeito de enunciação, ao destinatário e aos temas representados pelos autores.

Em tese recentemente defendida na área de Literatura Brasileira da usp, Critica Textualis in Caelum Revocata? Prolegômenos para uma Edição Crítica do Corpus Poético Colonial Seiscentista e Setecentista atribuído a Gregório de Matos Guerra, Marcello Moreira define e especifica minuciosamente os códigos bibliográficos dos códices da tradição gregoriana, criticando o uso transistórico das categorias filológicas do século XIX herdadas de Karl Lachmann e Joseph Bédier. Recusando a idéia de um autor fundador da unicidade da obra atribuída a Gregório de Matos como causa primeira dos textos e proposta como garantia da autenticidade e originalidade literária, entendendo-se "originalidade" como inovação estética e univocidade da origem, Moreira demonstra que os manuscritos da tradição gregoriana devem ser tomados como objetos que obrigam a redefinir o campo dos estudos filológicos e suas categorias, para produzir instrumentos mais precisos de análise histórica de textos anteriores ao século xIx romântico. $O$ estudo dos textos torna-se descritivo e não mais normativo. A crítica da categoria filológica "restituição do texto" significa, no caso dos códices gregorianos, a recusa de conceber a possível existência de um "texto original". A recusa é fundamentada pela reconstrução dos processos coletivizados de produção dos poemas, indiciados nas didascálias dos mesmos como oralidade e cópias avulsas, e da sua transcrição nos manuscritos, demonstrando a inviabilidade histórica da hipótese de que um "texto original" tenha existido no começo da tradição textual gregoriana e que tal texto, verdadeiro ideal edênico, tenha sido deformado por cópias sucessivas que, a cada vez mais, afastaram os leitores da verdade inicial, devendo por isso ser consideradas como não-confiáveis. Essa posição crítica, que incorpora pressupostos e procedimentos da New Philology inglesa, da obra de Paul Zumthor sobre a oralidade da poesia medieval e de sociólogos e historiadores, como Roger Chartier, Jean Hébrard, Armando Petrucci, D. Mckenzie, Harold Love, Jerome Mcgann, Hélène Merlin, entre outros, permite rediscutir os processos históricos que constituíram o autor e a autoria dos poemas atribuídos a Gregório de Matos desde a primeira metade do século xvirI. Moreira demonstra que o licenciado Manuel Pereira Rabelo fez a compilação dos poemas muito depois da morte do poeta em Recife, em 1696. Por que teve necessidade de organizar como manuscrito os poemas que circulavam na oralidade e em folhas volantes? E por que o fez na forma de "papéis vários"? Sob essa forma já existiam coletâneas de poemas de poetas nascidos no Brasil, além de portugueses e espanhóis, fei- 
tas por letrados de Salvador. Pode-se fazer a hipótese de que tentaria prolongar e consolidar uma tradição poética local com os textos do baiano Gregório. Ou a hipótese, seguindo-se o que afirma o mesmo Rabelo, de que se tratava de defender a memória do poeta contra seus detratores. Esta hipótese seria confirmada pelo fato de que a biografia, que põe no primeiro volume do códice, abrindo a compilação, tem por título Vida do excelente poeta lírico, o doutor Gregório de Mattos Guerra. O próprio título já desloca a compilação do campo baixo da sátira, que representa a maioria dos poemas, na direção do campo da poesia lírica então situada acima da sátira na hierarquia das belas letras.

Criticando as teorias lachmannianas, neolachmannianas e bédieristas de edição crítica, Moreira avança a proposta editorial de considerar a historicidade da tradição material dos códices gregorianos, refratária, segundo ele, ao que chama "teoria da edição que desconsidere seus caracteres históricos". Sua análise centra-se na unidade dos códigos lingüísticos e bibliográficos como elementos que constituem o artefato bibliográfico colonial, demonstrando que não são passíveis de dissociação em uma interpretação histórica de tradições bibliográfico-textuais que visa à formulação de propostas editoriais. Especificando os códices gregorianos como artefatos bibliográficos produzidos por uma cultura de escrivãos ou escribas, cuja existência na Bahia dos séculos xvII e Xvilı demonstra documentalmente, propõe a necessidade de circunscrever o conceito historicamente variável de "publicação" para torná-lo adequado à análise de tradições bibliográficotextuais produzidas pela manuscritura luso-brasileira. Na discussão dos códices manuscritos, propõe que os conceitos contemporâneos na base do trinômio sociológico autorobra-público não podem ser generalizados transistoricamente, devendo-se particularizálos, quando se trata de artefatos manuscritos de escribas coloniais, que incluem e produzem inúmeras variantes passíveis de ser definidas como a mouvance dos discursos medievais tratados por Paul Zumthor. Como afirma: "Expressões comumente empregadas em nosso estudo como 'meios letrados da América Portuguesa', 'práticas letradas na América Portuguesa', práticas escribais na América Portuguesa' et cetera não são meros rótulos que não podem ser definidos operacionalmente. Elas significam ou implicam agentes e/ou práticas produtoras de discurso/significação, mesmo que os agentes e práticas possam ser apenas inferidos por meio de indícios a nós fornecidos pelos artefatos bibliográficos produzidos pelos agentes e, por conseguinte, consubstanciadores de práticas letradas e escribais que só podem, necessariamente, ser apreendidas por meio dos objetos em que se materializam. As expressões por nós utilizadas não são, portanto, rótulos verbais, na medida em que se baseiam na análise e interpretação de dados empíricos - códices gregorianos seiscentistas e setecentistas - e não em valorações históricas prévias a qualquer análise de artefatos bibliográficos tangíveis" 34 . 
Letrados e autoria Ainda são necessárias mais pesquisas, como a de Marcello Moreira, que determinem as diferenças culturais das integrações produzidas na Colônia pela análise de seus meios materiais e suportes institucionais, de suas correspondências e fluxos internos, das iniciativas grupais e pessoais de letrados e artesãos do século xvir. Esquematicamente, a representação colonial pode ser descrita como resultado de processos técnicos - lingüísticos, retórico-poéticos, bibliográficos - e doutrinários ou teológico-políticos de integração e subordinação de diversos e diferentes códigos culturais, europeus, orientais, africanos e indígenas, adaptados às circunstâncias locais e deformados como valores-de-uso específicos das adaptações. Pressupondo-se a sincronia do Brasil e das colônias africanas e asiáticas de Portugal e a circulação de modelos retóricopoéticos da Espanha e suas colônias americanas, mas também de Roma e Nápoles, da Savóia, da Bavária, da Áustria, da França e da Europa central, no século xvir, a internacionalização dos esquemas da racionalidade de Corte das monarquias e principados católicos produzida principalmente pelas ordens religiosas, mas também pelo contrabando, circulação, cópia e deformações locais de textos manuscritos, impressos, gravuras, livros de empresas e emblemas etc., faz com que os letrados e os artesãos do Estado do Brasil e do Maranhão e Grão Pará conheçam a mesma referência retórico-teológicopolítica de base quando transformam poeticamente as matérias formais e informais dessas regiões. $\mathrm{O}$ que se evidencia, por exemplo, quando se comparam poemas satíricos de autores contemporâneos da auctoritas Gregório de Matos, como Caviedes, no Peru, e Sor Juana, no México, que não chegaram a ter conhecimento uns dos outros.

Os letrados que atuam no Estado Brasil são quase sempre pessoas da burocracia e do clero; geralmente, são formados nos cursos de Direito Civil e Canônico da Universidade de Coimbra3s. Como os artesãos, que realizam encomendas para confrarias, irmandades e ordens religiosas, os letrados dependem diretamente de mecenas ou patrocinadores.

34 MOREIRA, Marcello. Critica textualis in Caelum Revocata? Prolegômenos para uma edição crítica do corpus poético colonial seiscentista e setecentista atribuido a Gregório de Matos Guerra. São Paulo: 2001. Tese (Doutorado em Literatura Brasileira) FFLCH-LETRAS, Universidade de São Paulo, p. 251.

35 A escolha das letras também é condicionada pela instituição do morgado, conforme Rodrigues Lobo: "Têm as escolas, além destes, um bem, que favorece esta opinião, e é que de ordinário os que as buscam, ou são filhos segundos e terceiros da nobreza do Reino, que, por instituição dos morgados de seus avós, ficaram sem heranças e procuraram alcançar a sua pelas letras; ou são filhos dos homens honrados e ricos dele, que os podem sustentar com comodidade nos estudos; ou religiosos escolhidos nas suas províncias, por de mais habilidade e confiança para as letras". Cf. RODRIGUES LOBO, Francisco. "Diálogo 16". In: Corte na aldeia e noites de inverno, 1619. Lisboa: Sá da Costa.

$40 \neg$ João Adolfo Hansen 
Não conhecem, pelo menos imediatamente, a desqualificação das artes mecânicas trabalhadas pelos artesãos que, quase sempre mulatos, são socialmente tatuados pelo estereótipo da "limpeza de sangue". A partir da Academia dos Esquecidos, em 1724, é típico o patrocínio dispensado aos letrados por vice-reis. O letrado colonial não é ainda uma figura social justificadora de um imaginário social associado a ela ${ }^{36}$. Assim, não é ainda o "autor" ou o "escritor", no sentido iluminista e pós-iluminista do termo; mas também não é mais o "escrivão" de uma corporação de ofício medieval. Marcello Moreira demonstra, estudando a Conjuração dos Alfaiates, a permanência na Bahia, desde o século xVII até o final do XVIII, do que chama "cultura escribal" ou a prática da manuscritura exercida não só por padres, advogados, juízes e outros funcionários que receberam instrução que os habilitou nas letras, mas também por escribas engajados em profissões comerciais, como as contábeis, relacionadas à produção açucareira, que demandavam saber ler e escrever, além de conhecimentos de aritmética, como o indica o Regimento dos Almazens, redigido por ordem do Marquês de Fronteira, D. João de Mascarenhas, em 167437, que especifica as várias espécies de livros e as anotações que diariamente devem ser feitas neles por funcionários da alfândega.

Para esboçar a figura do letrado colonial, é útil determinar o valor ou os valores da sua representação numa sociedade de ordens em que a pessoa e sua posição se definem por pertencerem a um grupo, a uma ordem ou um estamento, pela representação e como representação, mais que por seus atributos individuais. A identidade social do letrado colonial não se define especificamente no campo das letras, como campo literariamente autonomizado, mas no de outros serviços. ${ }^{8} \mathrm{Um}$ índice disso é o número muito baixo de

36 VIALA, Alain. “Du caractère d'écrivain à l'Âge Classique”. In: Textuel. Images de lécrivain. Paris: Université de Paris Vll, 1989, n. 22, p. 51-2.

37 Regimento dos Almazens. No qual se dá a forma para o bom governo delles, e a recadação da Fazenda Real, e Regimento particular a cada hum dos Officiaes, para saberem o que the toca, e acudirem a sua obrigação. $O$ Marquez de Fronteira Dom loam de Mascarenhas. Lisboa, 10 de abril de 1674. (Cópia datilografada do Arquivo Público do Estado da Bahia).

38 A integração na hierarquia, que por definição impunha limites às ambições das iniciativas intelectuais, também produzia uma evidência pública de que a imagem de importância da representação dos letrados correspondia à realidade de uma distinção social. Ainda no final do século XVill, para ser admitido na burocracia, o letrado tinha de fazer prova de "limpeza de sangue", com sete testemunhas: "... é católico romano, solteiro, e bem regulado nos seus costumes; e que os sobreditos seus ascendentes nunca cometeram crime de lesa majestade divina ou humana, nem tiveram exercício mecânico: pois o pai do habilitando é Desembargador, e sempre teve a honra de empregar-se no Real serviço literário; e o avô paterno foi advogado na

Barroco, neobarroco e outras ruínas -41 
documentos iconográficos onde apareçam figuras de escritores; outro indício é a inexistência de qualificações como "autor" "escritor" ou "homem de letras" na papelada administrativa e jurídica portuguesa. Então, quem escreve é designado por categorias profissionais (Ouvidor Geral; Juiz de Fora; Desembargador; Vigário; Coronel da Milícia; Provedor dos Almazéns etc.); por categorias da posição (fidalgo/não-fidalgo) e, ainda, da própria formação letrada. Nos papéis portugueses, "letrado" quase sempre significa "formado em Direito por Coimbra" Ou seja, a posição letrada é determinada pelas categorias hierárquicas e profissionais da pertença ao "corpo místico" do Estado mais que pelas categorias que hoje definem a autoria. 39

》 referida cidade, aonde se tratou a lei da nobreza. Lisboa, 11 de setembro de 1778" - assim reza o documento do Corregedor do Cível sobre Tomás Antônio Gonzaga (Tratado de Direito Natural - Carta sobre a Usura. Obras Completas de Tomás Antônio Gonzaga. (Ed. Rodrigues Lapa). Rio de Janeiro: MEC/INL, 1957, p. 307, vol. ॥l). Ou: "... o habilitando pelos ditos seu pai e avós paternos é cristão velho de limpo sangue sem raça alguma de cristão novo, mouro, mulato, nem de outra infecta nação e menos dos novamente convertidos a nossa santa fé católica, porque nunca houve fama nem rumor em contrário", no caso de Inácio de Alvarenga Peixoto (Cf. LAPA, Rodrigues. Vida e Obra de Alvarenga Peixoto. Rio de Janeiro: MEC/INL, 1960, p. 160).

39 É útil relacionar a figura do letrado com a concepção de história corrente nos séculos XVII e XVIII. Modelada segundo os esquemas retóricos da crônica, acumula exemplos de ações e de eventos virtuosos, capturados pela enunciação no sentido ético do aconselhamento da "política cristã". Ou seja: a concepção ciceroniana da história como magistra vitae evidencia também a ordem e o sentido dados à experiência como reposição de padrões hierárquicos fundados na memória criteriosa de casos, narrados com grande erudição mitológica e poética extraída de autoridades latinas, patrísticas e escolásticas, segundo a tópica das "armas e letras". Nessa história, que pressupōe a hierarquia como um dado de natureza, a sociedade se organiza como o "corpo místico" no qual os indios, por exemplo, subordinam-se naturalmente como inferiores, uma vez que, lição da Política aristotélica, é próprio do inferior subordinar-se ao superior. Ao mesmo tempo, a apologia da hierarquia se acompanha do tema da difusão da Fé como a conquista espiritual que teria trazido a luz lusíada para o inferno verde. Logo, postos como excelência os critérios da hierarquia, da emulação, da discrição e o da conquista pela Fé e pelas armas, o letrado que os enuncia também se autorepresenta com os mesmos, constituindo-se como "melhor" não necessariamente por ser efetivamente um fidalgo ou um "melhor", mas por deter um saber que é uma memória da fidalguia que, permitindo-lhe prever novas aplicações, recicla os casos de sua própria definição como letrado. O que é típico das práticas da subserviência pois, juntamente com os tipos que são elevados na adulação, o letrado "sobe para baixo", quando demonstra sua capacidade de reconhecer a superioridade como um subalterno, prestando serviços, como aquele cachorrinho que abana o rabo para o amo, na divertida etimologia latina do ad + ululari de que fala Starobinski.

$42 \neg$ João Adolfo Hansen 
Por autor, hoje são entendidas várias coisas: o nome de um indivíduo empírico; a classificação que unifica uma obra ou um conjunto de obras; a classificação do regime discursivo em que a obra se inclui; a livre-concorrência; os direitos autorais; a propriedade da obra; a originalidade; o plágio. Muitas obras do século xvII, ao contrário do que ocorre com os apógrafos atribuídos a Gregório de Matos, levam o nome do indivíduo empírico que as inventa - por exemplo, os sermões de Antônio Vieira. Para contemporâneos, o nome indica um tipo que, sendo jesuíta, mestre de retórica, amigo de reis, inimigo da Inquisição, confessor da Capela Real, chefe de missão catequética, diplomata, orador sacro etc., não é, obviamente, uma subjetividade burguesa entendida como unicidade de sujeito psicológico dotado de direitos liberais, mas um tipo do poder real e tipo de poder local, em que convergem a generalidade dos interesses da Coroa e a particularidade dos interesses locais da Companhia de Jesus, ou seja, um tipo de uma ordem religiosa do padroado subordinado à Coroa, com certo caráter e decoro constantes, como a gravidade $\mathrm{e}$ a prudência que controlam seu humor colérico, fazendo-o discreto e especificando sua situação social, como representação, e os limites de seus privilégios como posição social exercida pela representação em contato, tensão e conflito com outras também exercidas como representações por meio de representações. Ou seja, tipo socialmente hierarquizado e sem a autonomia pressuposta nos direitos da subjetividade concorrencial do indivíduo autor nas sociedades contemporâneas ${ }^{40}$.

É fundamental observar, no caso, que Vieira atualiza em sua prática a formação recebida no seminário da Companhia de Jesus, cujo programa de ensino, formalizado no Ratio studiorum, implica a educação por assim dizer homogênea de todos os sacerdotes por meio da reciclagem maciça das autoridades canônicas da Igreja e das autoridades lógicas, dialéticas, gramaticais, poéticas, históricas e oratórias antigas. As várias disciplinas do Ratio studiorum implicam o treinamento da memória, da vontade e da inteligência do noviço com essas autoridades para formar o padre como total aptidão para desempenhar os interesses da Companhia, da Igreja e da Coroa nas coisas do mundo. A Vieira seria não só impensável como impossível a pregação autonomizada da sua educação e da disciplina de sua Ordem, que formam e conformam sua prática de orador, impondo e delimitando o

40 Como diz Vitorino Magalhães Godinho: "O funcionalismo, que, nos seus escalōes superiores pelo menos chegara a constituir uma ordem separada - a dos letrados - , integra-se em boa parte no braço nobiliárquico ou sua ante-câmara: a carreira leva a receber o título de escudeiro, e depois o de cavaleiro, atingindo-se o grau de cavaleiro fidalgo ou mesmo acima. Tal simbiose, parcial embora, introduz necessariamente a ambigüidade na condição e mentalidade do funcionalismo". In: GODINHO, Vitorino M. Estrutura da antiga sociedade portuguesa. 3.ed. Lisboa: Arcádia, 1977, p.102-3.

Barroco, neobarroco e outras ruinas $\ulcorner 43$ 
"dever ser" de sua ação como jesuíta imiscuído nos negócios temporais. Como pregador, Vieira é um tipo social totalmente previsto pelas Constituições e Regras da Companhia de Jesus: realiza publicamente o vínculo de obediência à sua Ordem ${ }^{41}$, executando com mestria inigualável os mesmos padrões retórico-doutrinários recebidos na educação por todos os seus irmãos em Cristo que também fizeram o seminário, Teologia e os votos e, como ele, receberam a mesma instrução que os torna aptos para também pregar. É como tipo social que atualiza na prática oratória uma formação comum rigidamente regrada como autoridades canônicas e retórico-dialéticas que Vieira é um autor.42 Seu nome significa a autoridade do exercício de um gênero popular contra-reformista - o sermão sacro no sentido latino de auctoritas ou modelo da excelência de um desempenho emulado por outros oradores sacros. Como tipo subordinado de uma ordem religiosa subordinada à Coroa e a Roma, como tipo especificado por um caráter e um decoro de padre jesuíta, como autoridade de um gênero sacro, Vieira tem a posse dos sermões que inventa: são seus, pode mesmo lamentar o mau uso deles e do seu nome, como o faz, acusando a deturpação da auctoritas. Não tem, porém, a propriedade dos sermões, que correm publicados em cópias manuscritas e editados em letra impressa como "sermões de Vieira" atribuídos à sua auctoritas; seus sermões também não têm originalidade, no sentido romântico da mercadoria - originalidade concorrendo com outras originalidades no mercado de bens culturais, porque Vieira aplica e transforma matérias, formas e preceitos objetivos

41 Cf. LOIOLA, Santo Inácio de. Constituições da Companhia de Jesus. Trad. e notas de Joaquim Mendes Abranches,

S.J. Lisboa: Província Portuguesa da Companhia de Jesus, 1975. Veja-se, por exemplo, [77]: " Se as pregações e ministérios se exerceram noutras partes distantes do lugar e da casa, deverá trazer um atestado dos sítios onde tiver passado um tempo notável, ou das autoridades públicas (tendo grande conta de todos os Ordinários), que dê plena garantia de que semeou a palavra divina e cumpriu o ofício de Confessor com sã doutrina, bom exemplo de vida, e sem ofensa de ninguém"; [109]: "Para exercer o ofício de semeador e ministro da palavra divina e se dedicar à ajuda espiritual do próximo, convém ter suficiente cópia de conhecimentos intelectuais" (p. 63); [111]: "Para maior humildade e perfeição dos homens de letras, Coadjutores espirituais e Escolásticos, se houver dúvidas sobre a suficiente aptidão de algum dos candidatos à Companhia para nela ser Professor, Coadjutor espiritual ou Escolástico, deverá ter-se em conta que é muito melhor e mais perfeito para ele deixar-se julgar e governar por ela. Esta saberá, tão bem como ele, o que se requer para viver nela; e o súbdito mostrará maior humildade e perfeição, e dará provas de maior amor e confiança naqueles que o devem governar" (p.64). Cf. [404],[405], que prescrevem como formar excelentes pregadores.

42 Cf. [814]: "Assim, devem-se cultivar cuidadosamente os meios humanos ou os adquiridos com o próprio esforço, especialmente uma doutrina fundada e sólida, e a maneira de a apresentar ao povo em sermões e liçōes sacras, e de tratar e conversar com as pessoas". Ibid.

$44 \neg$ João Adolfo Hansen 
que não são seus, mas propriedade comunitária da Companhia de Jesus e do "bem comum" do Império, como as disciplinas e matérias do ensino ministrado por sua Ordem em sua formação e reproduzidas por ele na pregação que repõe as mesmas auctoritates comunitárias da oratória, como Cícero, Crisóstomo, Paravicino; nem são dotados de autonomia estética, porque, num tempo orientado providencialmente por Deus, sua auctoritas não conhece a divisão do trabalho intelectual e o trabalho intelectual da divisão iluministas e pós-iluministas que tornam os regimes discursivos especializados; sua auctoritas também não dissocia sua prática de orador da metafísica neo-escolástica que a motiva como a palavra de Deus difundida como testemunho de um tipo da devotio moderna da Companhia de Jesus imediatamente empenhada nos assuntos temporais do Império, como os capitais judaicos, o tráfico negreiro, a escravidão de índios, a competição comercial.Vieira é um letrado, no sentido de fazer parte da "gente de letras" de seu tempo, podendo-se dizer que letrado é entendido mais como um caráter, ou um éthos, que propriamente como uma individuação autoral no sentido contemporâneo de "autor" definido pela livre-concorrência. Em outras palavras, pelo termo letrado significa-se então um tipo dotado de certas qualificações técnico-profissionais que o situam na intersecção de uma forma de atividade religiosa ou econômica com outra, simbólica: é alguém que exercita as "letras" - entendidas genericamente, aqui, como as várias auctoritates do costume antigo recicladas na imitação, não em termos "literários" de autonomia estética, contemplação desinteressada, originalidade e direitos autorais - recebendo, com isso, certa qualificação produtiva (por exemplo, mestre de retórica) e, por vezes, certa distinção nobilitante (por exemplo, orador da Capela Real). No caso, distinção grande, pois a excelência discreta do seu método escolástico de pregar o torna modelo ou auctoritas do método jesuítico e português de pregar. Para definir o letrado colonial, é preciso, enfim, determinar o valor ou os valores de sua representação numa sociedade de ordens em que a pessoa e sua posição se definem como representação e pela representação da subordinação ao "bem comum" do Império, mais que por seus atributos individuais, como na fórmula portuguesa "gente de representação". Ou seja, posição determinada pelas categorias da pertença ao corpo místico do Estado, mais que pela autonomia autoral, originalidade estética e invenção literária.

A representação que o letrado colonial produz, principalmente em português, mas também em espanhol, italiano, latim e tupi, é mimética, como disse, feita como aplicação de técnicas retóricas anônimas e coletivizadas que prescrevem a emulação de modelos de autoridades que adapta as referências institucionais e informais do lugar a interesses específicos. As adaptações produzem deformações de vários graus e valores, que repetem sistemicamente as prescrições técnicas dos esquemas imitados e os critérios contemporâneos de julgamento do seu valor. As deformações são diferenças materiais, formais,

Barroco, neobarroco e outras ruínas -45 
institucionais e pessoais, como intervenção particular que reproduz o padrão coletivo. A representação colonial não conhece, evidentemente, a divisão dos regimes discursivos produzida a partir do Iluminismo: não é "literária", objeto de uma estética que teorize sua contemplação desinteressada. Seu fundamento é o substancialismo da metafísica neo-escolástica, que é útil considerar para definir os pressupostos e fins hierárquicos e últimos dos seus usos retoricamente prescritos 43.

Tempo, história e metafísica Koselleck propõe que a relação de "experiência do passado", entendida a expressão como o modo ou os modos pelos quais determinada formação histórica formaliza a experiência da ruína da formação que a antecedeu, e "horizonte de expectativa do futuro", o modo como representa a (im)previsibilidade do que virá, é um critério historiográfico pertinente para se determinar a maneira ou as maneiras como o presente da sua história é figurado nas representações que produz.44 Quando se faz a questão acerca dos modos de representar a experiência do passado e a expectativa de futuro para os resíduos do século XvII, algumas especificidades aparecem. Elas excluem imediatamente as categorias da categoria "barroco". No caso, a metafísica é outra. A principal dessas especificidades é o modo qualitativo pelo qual concebem a temporalidade como emanação ou criação de Deus que inclui a natureza e a história, subordinando-as providencialmente no projeto de salvação. A representação propõe que a natureza e a história são simultaneamente efeitos criados por essa Causa e signos reflexos dessa Coisa, ou seja, que ela mesma, representação de efeitos e signos, é signo e efeito. A história, incluída no tempo como uma de suas figuras proféticas, é concebida providencialmente, pois recebe do tempo, que é criado, sua participação na substância divina, que a aconselha e orienta para um fim superior. A concepção relaciona a experiência do passado e a expectativa do futuro como previsibilidade, pois afirma-se que a Identidade de Deus, Causa Primeira, repete-se em todas as diferenças históricas do tempo, tornando análogos ou semelhantes todos os seus momentos, desde a Criação até o presente dos intérpretes. Articulando essa repetição, Vieira escreveu uma História do Futuro, título que ficou paradoxal desde a segunda metade do século xvIII, quando a história se constituiu como a disciplina do que não mais se repete ou do que só se repete como farsa da tragédia que foi na primeira vez. É útil tratar desse modo particular de definição do acontecimento históri-

43 Refiro-me às artes luso-brasileiras determinadas teologicamente pela neo-escolástica; evidentemente, no século XVII, existem artes ordenadas por prescrições apenas retórico-poéticas.

44 KOSELLECK, Reinhardt. "Le futur passé des temps modernes". In: Le futur passé. Contribution à la sémantique des temps historiques (Traduit de l'allemand par Jochen Hoock et Marie-Claire Hoock), Paris: EHESS, 1990.

$46 \neg$ João Adolfo Hansen 
co figurado como repetição da Identidade divina, para especificar a natureza metafísica da normatividade teológico-política e retórico-poética das representações coloniais.

Para tanto, é oportuno especificar o que são a linguagem e o corpo na representação do século xvir. Pode-se dizer, de modo sumário, que nela a linguagem é, antes de tudo, uma jurisprudência ou usos autorizados dos signos, que prescrevem que todas as imagens, discursivas, plásticas, musicais, gestuais, devem ser boas imagens reguladas ou controladas em regimes analógicos de adequações verossímeis e decorosas. Aqui, a concepção de signo é outra, não-cartesiana, pois não distingue "conceito" de "imagem", por isso também é exterior aplicar às representações coloniais o par "significante/significado" da lingüística saussureana e pós-saussureana. A representação é uma estrutura quádrupla, pois também a substância da expressão e a substância do conteúdo, classificações da lingüística contemporânea do que não é distintivo na definição da estruturalidade das línguas, significam, uma vez que a substância sonora das línguas e a substância espiritual da alma são signos e efeitos reflexos da sua Causa. Na substância sonora das línguas então se lêem os índices da língua adâmica e de Babel, o que autoriza enunciados como o da falta de Fé, de Lei e de Rei dos tupis do litoral brasileiro, quando se observa, no século Xvi, que sua língua não tem os fonemas $/ \mathrm{f} /, / \mathrm{l} /, / \mathrm{r} /$. Ou as etimologias das claves universales, estudadas por Paolo Rossi45, que se tornaram fósseis intelectuais fantasiosos nas interpretações feitas depois da segunda metade do século xvıII. Do mesmo modo, a substância da alma, definida como unidade de memória, vontade e inteligência, é iluminada pela Graça, que a predispõe ao Bem. Aqui, as apropriações neoescolásticas da mímesis aristotélica compõem os efeitos das representações como semelhança e diferença por participação analógica da linguagem na substância metafísica de Deus. Segundo as representações, Deus, Causa Primeira e Final da natureza e da história, ilumina o juízo dos autores no ato da invenção, que estabelece relações simpáticas e antipáticas, agudas e vulgares, prazerosas e desprazerosas, eficazes e afetadas, mas sempre regradas segundo os verossímeis dos gêneros e os decoros específicos das ocasiões da hierarquia. Sendo neo-escolástica e pré-cartesiana, essa jurisprudência não subordina a representação a uma razão suficiente, como cogito, mas aos fantasmas ou imagens da fantasia. Diferentemente do cartesianismo, não distingue idéia de imagem, como conceito inteligível e imagem sensivel, pois define a imagem como formulação e visualização simultaneamente intelectuais e sensíveis da idéia. Antes de sua representação exterior, as imagens mentais são definições ilustradas, como propõe Cesare Ripa,

45 Cf. Rossı, Paolo. Clavis Universalis. Arts de la mémoire, logique combinatoire et langue universelle de Lulle à Leibniz. Traduit de l'italien par Patrick Vighetti. Grenoble: Jerome Millon، 1993.

Barroco, neobarroco e outras ruínas -47 
imitadíssimo, no "Proêmio" do Iconologia, em 1593: antes da sua representação exterior, são conceitos intelectualmente visíveis como entimemas ou silogismos retóricos produzidos dialeticamente pelo juízo. A forma-matriz de qualquer imagem é a metáfora, pois a imagem-conceito é inventada associativamente pela fantasia aconselhada do juízo, que aproxima e condensa outras imagens-conceito fornecidas pela memória dos bons usos, estabelecendo novas associações imaginárias com elas por meio das semelhanças e diferenças que as especificam. Definida como presença da Luz divina na consciência, segundo as analogias de atribuição, proporção e proporcionalidade, a imagem faz ver, quando representada exteriormente, a Causa que orienta a operação lógico-dialético-retórica que a inventa. No caso, afirma-se que o atributo do Ser aplica-se a todas as coisas da natureza e eventos da história, fazendo-os convenientes entre si; por isso mesmo, diversos e diferentes. Todos os seres são semelhantes per ordinem ad unum ou ad maximum, como doutrina Santo Tomás de Aquino, recuperado pelos preceptistas do século XVII. E em todos os análogos, enquanto são análogos, sempre se põe o Um como definição de todos os outros46. O estilo acumulado das representações decorre não de irracionalismo "barroco", mas da teatralização da presença divina nos gêneros, espécies, indivíduos e acidentes hierarquizados dos seres criados. A proliferação sensível dos seres, metaforizados, opostos, deformados, espelhados, dobrados, alegorizados, acumulados realiza a presença da Unidade para destinatários incluídos e integrados nos estilos como testemunhos do Fundamento da ordem hierárquica, que difunde, impōe e defende sua Ordem na defesa militar, na exploração econômica e na conquista espiritual do território.

Teologia-política e poder No caso, é útil lembrar, com Kantorowicz, que nos séculos XVI e XVII, sob a autoridade do papa como princeps e verus imperator, o aparelho hierárquico da Igreja Romana mostrou uma tendência a se tornar o protótipo perfeito de uma monarquia absoluta e racional sobre uma base mística, enquanto que, simultaneamente, o Estado manifestou mais e mais uma tendência a tornar-se uma quase-Igreja e uma monarquia mística sobre uma base racional.47 $\mathrm{Na}$ teoria do poder dessa "quase-

46"(..) in analogis omnibus, in quantum analoga sunt, semper unum ponitur in definitione aliorum". Sto. Tomás de Aquino. Summa theol., p. I, q. 13, aa. 5, 6,10.

47 KANTOROWICZ, Ernst. "Mysteries of State". In: Selected studies. New York, 1965, p. 382. Apud COURTINE, Jean François. "L'héritage scolastique dans la problématique théologique-politique de l'Âge Classique". In: MECHOULAN, Henry (dir.). Létat baroque 1610-1652. Regards sur la pensée politique de la France du premier XVIle siècle. Étude liminaire de Emmanuel de Roy Laduire. Préface de André Robinet. Paris: Librairie Philosophique J. Vrin, 1985, p. 110.

$48 \neg$ João Adolfo Hansen 
Igreja e monarquia mística sobre uma base racional", a metáfora do corpo, modelo do corpo político da sociedade doutrinado por Santo Tomás de Aquino como unidade de integração, impõe-se nas instituições e processos do pacto colonial. A imagem das partes pacificadas e integradas do corpo do Estado como "bem comum" do todo difunde-se nas representações em que o ser social dos indivíduos identifica-se à representação que fazem de si para outros. O reconhecimento da posição a partir de signos visíveis de honra e poder fundamenta as representações em práticas cujo modelo distante, presente nas instituições, é a Corte. O consumo ostentatório de signos é fundamental, regulandose todo dispêndio de acordo com as exigências juridicamente codificadas da posição. A identidade é definida como representação - uma forma específica da posição - e pela representação - uma ocasião de sua aplicação como aparência decorosa. Na vida de relação dramatizada nos discursos, o poder se deduz da aparência e, a posição, da forma da representação48. O que obviamente implica os conflitos das representações e sua identidade instável, uma vez que o favor real pode alterá-las a qualquer momento, pois é o Rei quem detém os privilégios como cabeça do corpo místico.

Na expressão "corpo místico" corrente nas representações coloniais, fundem-se duas articulações: uma delas é teológica, o "corpo de Cristo", a hóstia consagrada pela Eucaristia, e, por extensão, a respublica christiana, o corpo da Igreja. A outra articulação é jurídica, oriunda da teoria da corporatio, a corporação romana, e da noção medieval de universitas, e, principalmente, relacionada à doutrina da persona publica, nome dado por Santo Tomás de Aquino à noção jurídica de persona ficta ou persona repraesentata. Os juristas contrarreformados juntaram à noção de respublica a de corpus mysticum, fundando com ambas a de corpo político. É a doutrina suareziana do pactum subjectionis do todo do reino como "corpo místico", que fundamenta a sistematização e a centralização do poder monárquico e a conceituação do "bem comum", que no século xvil define o estatuto jurídico da pessoa em Portugal e no Brasil. Lutero e outros reformados afirmam que o poder decorre diretamente de Deus, que envia os reis para impor ordem à anarquia dos homens corrompidos pelo Pecado original. Por meio dos jesuítas, principalmente, a Igreja Católica combate as teses reformadas, afirmando que Deus certamente é origem do poder, como causa universalis ou causa universal da natureza e da história, mas não causa direta do mesmo, pois o poder decorre de um pacto de sujeição. Logo, a conceituação da natureza do Direito Natural que estrutura a forma mentis e a posição social dos súditos luso-brasileiros no pacto de sujeição é fundamental na definição do estatuto jurídico da "pessoa humana" figurada nas representações.

48 ChartIER, Roger. "Trajectoires et tensions culturelles de l'Ancien Régime". Mimeo. Paris: EHESS, 1989.

Barroco, neobarroco e outras ruínas $r 49$ 
Antônio Manuel Hespanha e Maria Catarina Santos demonstram que a conceituação corrente em Portugal nos séculos Xv I X Xvi postulava que, antes de ser uma vontade (voluntas), o Direito era uma razão (ratio, proportio, commensuratio, ordo, ius, juízo, prudência). Como a teoria fundamentava a legalidade e a legitimidade do Direito ou as leis positivas do reino na luz natural da Graça inata, o dito "direito comum" ou "ordinário" (ius commune, opinio communis, "praxística") tradicionalmente escapava ao arbítrio da razão de Estado absoluta, que era a esfera própria da vontade da persona ficta ou pessoa mística real. Conforme os autores citados, era consenso que o direito ordinário existia independentemente, antes da sua volição pelo rei. Também era consensual que seu conhecimento e aplicação dependiam de um saber específico, que devia ser repetido por uma categoria também específica de homens, os letrados, principalmente os formados no curso de Cânones ministrado pelos jesuítas na Universidade de Coimbra. Depois da obra de Maquiavel, que passou a determinar no mundo católico o problema de teorizar o poder mantendo seu antigo fundamento ético, a doutrina da razão de Estado absoluta passou a afirmar, muitas vezes, que o direito ordinário se incluía nela; em Portugal, contudo, como Hespanha e Santos evidenciam, perdurou a noção tradicional de uma jurisprudência paralela à vontade da Coroa, constituindo-se mesmo, como se fosse uma evidência, a noção da legitimidade do controle jurídico do poder central do rei pelos tribunais e, por isso, também a idéia muito difundida de que o rei não poderia governar sem o conselho dos juristas, que era considerado mais básico que o das Cortes. Se o rei o fazia, agia contra a ratio iuris. Além disso, quando se tratava da aplicação, da integração e da interpretação do Direito, a presença dos juristas era sempre muito ativa. Devese somar a essa importância da jurisprudência e dos juízes a lentidão da máquina judiciária portuguesa, sempre emperrada pelos pleitos, agravos e desagravos 49 , juntamente com a larga margem de arbitrium nas decisões, facultada pela estrutura doutrinária e burocrática do saber jurídico. Evidencia-se imediatamente a centralidade do lugar social dos juristas na sociedade luso-brasileiraso e, em decorrência, também das formas do pensamento jurídico difundidas por todo o corpo político do Estado pela educação

49 Cf. sCHWARZ, Stuart B. Burocracia e Sociedade no Brasil Colonial. São Paulo: Perspectiva, 1979; Sugar plantations in the formation of Brazilian Society. Bahia 1550-1835. Cambridge: Cambridge University Press, 1985 (Segredos internos: engenhos e escravos na sociedade colonial, 1550-1835. (Trad. Laura Teixeira Mota), São Paulo: Companhia das Letras, 1988).

50 HESPANHA, António Manuel e SANTOS, Maria Catarina. "Os poderes num império oceânico". In: MATTOSO, José (Dir.) e HESPANHA, António Manuel (Coord.) História de Portugal. OAntigo Regime (7620-1807). Lisboa: Editorial Estampa, 1982, v. 4، págs. 395-413.

$50 \neg$ João Adolfo Hansen 
odelo de distinção social emulado por todos, dos escravos aos príncicomo as formas da agudeza, na poesia e na prosa, que reproduzem a guos da filosofia escolástica aprendida pelos letrados nas instituições ência, legalismo, casuísmos, providencialismo, sutilezas, exames de ismo das fontes e muito latim são constitutivos de um modo histórico se trata, como se diz anacronicamente, de fórmulas verbalistas e fúteis lidade. Ao contrário, sāo absolutamente reais e ativamente constitutio seu tempo.

genho e agudeza Pode ser útil, por isso, lembrar que uma antiga pera nas representações coloniais, formando-a de razão particular e primeira, também chamada cogitativa nos cursos de Teologia do ColéUniversidade de Coimbra, tradicionalmente é aquela que só entende s e corruptíveis. Toda arte aplica-se a amestrá-la, mantendo-a sob cone a falta de discernimento que a caracteriza é rústica, especificando o e confuso de vulgares. A outra, razão universal, é própria de "entendipois considera sempre as coisas universais despojadas de toda paixão ttes e, por conseguinte, distingue-as incorruptíveis, enquanto lhes aplide-se em duas partes, intelecto contemplativo e intelecto ativo. No pritrês hábitos contemplativos: um é propriamente o intelecto, como co'rimeiros Princípios; o segundo é a sapiência que, embora compreenda ceiro, distingue-se deles; o último é ciência. Intelecto, sapiência e ciên, engenho natural dos autores das letras; seu exercício, feito como freação de autoridades, segue a lição de Quintiliano, que prescreve a enarelenco de autores que devem ser memorizados e imitados, e de Cícero, modos como se demonstra adequadamente a qualidade das matérias. ou intelecto ativo, cujo fim não é propriamente entender, mas operar e dois hábitos práticos: $o$ agível, em que está contida a prudência, cabeça les morais, como recta ratio agibilium, reta razão das coisas agíveis, e o ta ratio factibilium, reta razão das coisas factíveis, que em si contém rte é um hábito intelectivo que faz com certa razão algumas coisas que as; ou, melhor dizendo, um hábito factivo que pressupõe a aptidão do ge a natureza. Diferentemente da disposição, o hábito factivo ou arte é -me e estável, decorrente da experiência; e, diferentemente da prudên$n$ seu princípio, aristotelicamente doutrinado, na experiência do costuizada numa prática e técnicas ensináveis. No século XVII, tanto mais 
nobre é a arte quanto mais nobre é seu fim. Segundo Vieira, seus sermōes são “choupanas" que visam a persuasão que integra todas as ordens do Império no pacto de sujeição, mas suas obras proféticas são "palácios", pois visam a realização final dos fins pregados nos sermões, o segundo advento de Cristo. A profecia é superior ao sermão, segundo o juízo do jesuíta, porque seu fim não é deste mundo, embora todos os meios humanos para realizá-la livremente estejam postos no grande teatro do mundo, entre o livrearbítrio dos súditos e os acasos da Fortuna madrasta.

Propondo a dupla legibilidade de coisas e palavras, uma legibilidade factual e uma legibilidade verbal, a íntima fusão de teologia e política das representações afirma que também a empiria é racional, pois apresenta as marcas da racionalidade eterna que devem ser interpretadas por hermeneutas autorizados, que dominam a verdade dos textos canônicos e da traditio confirmados na sessão de 8 de abril de 1548 do Concilio de Trento, ao contrário justamente dos lugares maquiavélicos, erasmistas, luteranos, calvinistas, galicanos ou já hobbesianos, onde a luz natural da Graça inata é hereticamente considerada ausente ou não necessária na fundamentação do poder político. Nenhuma representação colonial luso-brasileira do século XvII, ou seja, representação da "política católica" ibérica, deixa de incluir, como termos que fundamentam sua autoridade, teologemas testamentários que definem sua eficácia, nos variados negócios do tempo, como manifestação da luz da Graça da sua Causa Primeira refletida na legalidade e na legitimidade dos códigos positivos impostos pela Coroa.

Os textos dos tratadistas italianos, espanhóis e portugueses que circularam no Estado do Brasil e no Estado do Maranhão e Grão Pará, e que nos séculos xvi, xviı e xviı doutrinaram o desenho interno, como a forma luminosa do desígnio da Presença divina na consciência, como Gilio, Possevino, Borghini, Ripa, Peregrini, Otonelli, Pallavicino, Tesauro, Gracián e Francisco Leitão Ferreira, afirmam, como versões neo-escolásticas de Aristóteles, que a imaginação inventa as imagens dos objetos ausentes operando sobre os fantasmas da mente iluminada da Luz. Para isso, ela seleciona as tópicas, os tropos e as figuras adequados ao gênero da obra em uma memória de usos autorizados, produzindo uma representação ou uma visualização que torna o objeto intelectualmente conhecido. Em todos os casos, não se trata de estética, mas de retórica e poética. Quando autêntica, a imaginação é sempre acompanhada do juízo, que o intelecto aciona dialeticamente, fazendo anatomias, definições, análises e contradefinições dos temas, enquanto faz predicações, produzindo a metáfora do objeto que é conhecido intelectualmente. Aqui se observa imediatamente a abstração intelectualista do aristotelismo característico do processo mimético dessas práticas: nos fantasmas da mente, o intelecto agente, guiado pela luz da Graça, ilumina os aspectos inteligíveis dos objetos materiais, imprimindo as espécies 
deles no intelecto cognoscitivo na forma de uma imagem que é metáfora. Tesauro a chama de ornato dialético; Gracián, de silogismo retórico e entimema. Outros falam de conceito engenhoso. Todos eles, de agudeza, nenhum deles de "barroco", pois a abstraçāo é uma iluminação do engenho que estabelece a relação inesperada de dois conceitos, como diz Aristóteles, quando especifica a astéia, ou ainda, como escreve Cajetano, uma iluminação da mente participada que, incidindo sobre o objeto, também faz com que a iluminação se irradie dele e demonstre relações inesperadas entre seres e conceitos. Os efeitos da Luz, como aspectos inteligíveis dos objetos, fazem com que o destinatário deduza, no estilo das obras, o ato iluminado da abstração aplicada. Ao mesmo tempo, a cognição dos efeitos põe em evidência a sua Causa Primeira, como Presença que faz o mundo ser e desejar o Ser. No caso, o efeito da Luz é duplo, formal e objetivo. Formalmente, é o efeito de presentar algo irrepresentável na representação, dando-lhe forma, ou seja, tornando luminoso e determinado o invisível e indeterminado do conceito de Deus, quando dá visibilidade ao corpo posto entre os objetos da experiência e a Luz divina e a luz material. Simultaneamente, o corpo das imagens que é tornado visível pelo intelecto em ato é também condição objetiva da visibilidade das operações do próprio intelecto em ato. Por ser iluminado pela Luz invisibilíssima, realiza sua presença fugidia e imaterial. E como se supõe sempre, com o Pseudo-Areopagita, que supremum inferioris attingit infimum superioris, que o grau supremo do inferior atinge o grau ínfimo do superior, tem-se, como em Leibniz, o princípio da continuidade do Universo como correspondência analógica dos seres conhecidos nas imagens.

Em algum lugar, Luhman lembrava que não vemos a causa da luz, o Sol, mas coisas na luz. Da mesma maneira, não lemos letras, mas, com o auxílio do alfabeto, palavras; e, se quisermos ler o próprio alfabeto, teremos de ordená-lo alfabeticamente. A coordenação de elementos produz a forma, mas o próprio meio de suporte ou de coordenação da forma geralmente não chama a atenção. Nas representações coloniais luso-brasileiras do século Xvir, vêem-se coisas na luz e também se vê a Luz; lêem-se palavras, significantes, mas também a substância das letras e a substância dos sons. Para usar uma expressão de Hans Ulrich Gumbrecht, a representação é um dispositivo de produção de presença, ou seja, um dispositivo teológico-político de produção da Presença divina nas instituições coloniais. Os grandes tópicos seiscentistas do "sonho da vida" e do "teatro do mundo" correntes nas letras do século XVII, são uma cena alegórica que ficcionaliza a iluminação generalizada do pensamento da ficção pela Luz.

No caso, o corpo místico e glorioso de Cristo é irrepresentável ou só se presenta em figurações alusivas, que o profetizam e confirmam como substância espiritual participada nos objetos representados sem confundir-se com eles. Como idéia de Deus, está absoluta- 
mente fora do tempo e, contudo, no tempo, participando dele com o amor do seu ato diretivo. Uma das principais finalidades das representações coloniais é justamente encenar essa participação de todos os tempos na Presença. Como ocorre na figuração da gestualidade dramática dos santos de Bernini nas igrejas de Roma ou nas igrejas da Bavária, de Tunja, Puebla, Querétaro, Pernambuco, Bahia e Minas Gerais, a representação encena o momento da conformatio, a conformação, o momento da produção do afeto no destinatário.

Le Brun, em L'expréssion des passions, as conferências que fez em Versailles em 1668, afirma que o fim da representação é figurar os movimentos da alma através das atitudes dos corpos para que, vendo as imagens pintadas e esculpidas, o espectador exercite a imaginação, produzindo em si mesmo a presença de um afeto cuja forma deve ser a mais semelhante possível à forma do afeto representado no corpo esculpido ou pintado do santo51. O momento representado como conformação é justamente o do instante inefável do contato com Cristo ou da recepção da Graça, que os teólogos chamam de conformação afeti$v a$, sublinhando seu caráter passional. Na escultura religiosa das igrejas coloniais baianas e mineiras, por exemplo, as torsões do corpo, ordenado dramaticamente como uma figura serpentinata, pela qual as personagens representadas dispõem-se como um $\mathrm{S}$ em torno de um eixo imaginário que as atravessa da cabeça aos pés, são realizadas segundo o cálculo cenograficamente exato de uma ação aplicada como deformação que representa uma paixão da alma. Ação, deformação, paixão: a escultura religiosa figura a conformatio, o momento do contato do corpo do santo com o corpo místico de Cristo; as várias posições possíveis de dedos, mãos, pernas, pés, olhos e boca compõem, no próprio estilo, tópicos apaixonados e o lugar da sua observação adequada pelo destinatário que recebe o efeito. A escultura prevê a distância exata; no espaço da igreja, o espectador deve ocupar a mesma posição calculada para ser persuadido da presença da luz da Graça e ser edificado com ela, nela e por ela. As letras, poesia e prosa, hoje classificadas como "barroco", ordenam a forma de maneira equivalente à conformatio por meio das agudezas.

No século xviI, "afeto" diferia de "ação" e, como no poema de John Donne, em que o personagem diz a Deus que nunca poderá ser livre e casto a menos que Ele o estupre never shall be free/ Nor ever chaste, except you ravish mee - "estar apaixonado" então significa deixar que outra vontade aja sobre o corpo, produzindo nele a presença deformante de sua força. Aqui, em chave neoplatônico-agostiniana, tanto o discursivo quanto o plástico são figurações da infusão mística da Luz² e, conforme o modelo da Eucaristia,

51 LE BRUN, Charles. L'expréssion des passions et autres conférences. Correspondance. Paris: Dédale Maisonneuve et Larose, 1994.

52 CARERI, Giovanni. "El artista". In:VILLARI, Rosario y otros. El hombre barroco. Madrid: Alianza Editorial, 1993, p. 335. 
figurações da incorporação da luz natural da Graça pelos corpos operados como dispositivos de produção da Presença. A teologia é política: as representações intensificam a desqualificação da carne insubmissa à hierarquia, enquanto exaltam, em signos de posiçāo discreta, o corpo que se subordina, propondo que o sentido do teatro está além ou que só é autorizado quando se representa politicamente como participação do corpo individual no corpo místico da comunidade. Obviamente, porque nunca pode apresentar um grau zero de si mesmo, o corpo é sempre um objeto semiótico; a representação dele segundo essa metafísica da Luz é homóloga da figura do "corpo místico" definido nos tratados dos juristas contra-reformistas difundidos pela Companhia de Jesus em seus colégios e seminários, como De legibus e Defensio fidei, de Francisco Suárez, ou Della raggion di Stato, de Giovanni Botero.

O Direito Canônico português, que regula a legalidade e a legitimidade das práticas da colonização do Brasil e do Maranhão e Grão Pará, prescreve que os corpos individuais se integram na vontade unificada do corpo místico do Estado definido pela doutrina do pacto de sujeição. Doutrinado por Suárez segundo o modelo jurídico da escravidão como quasi alienatio da comunidade que, como uma única vontade unificada, transfere o poder para o rei, o pacto de sujeição especifica os modos hierárquicos como as três faculdades escolásticas que então constituem a pessoa - memória, vontade, intelecto - devem agir como faculdades súditas ou subordinadas. O corpo individual só é visível e dizível quando sua memória, sua vontade e sua inteligência se integram e subordinam-se nos vários corpos de ordens ou na hierarquia corporativa do "bem comum" do Estado. Não há nenhuma noção de subjetividade psicológica, como é normalizada hoje, nas representações dessa subordinação; por isso, a posição do eu nessas práticas é imediatamente a de uma subordinação da vontade, da memória e do intelecto em formas do todo social objetivo como livre-arbítrio que parece paradoxal para a experiência iluminista, pois é liberdade definida como subordinação. Subordinação dos apetites individuais à unidade estóica da tranqüilidade da alma dada a ver, ouvir e ler nos signos espetaculares da Luz; subordinação da tranqüilidade da alma à concórdia pessoal em relação ao todo dada a ver no espetáculo; por decorrência, subordinação da vontade, da memória e do intelecto à paz individual e coletiva, decorrente da subordinação das partes e do todo ao Ditado divino da Igreja garantido pela Coroa. Aqui, a intensa sensorialidade das metáforas evidencia justamente a Presença que legitima a representação. A sensorialidade é um diagrama do sentido geral dessa integração fornecido ao destinatário como critério avaliativo do efeito. Em um tempo, em um lugar e em práticas nos quais não há "opinião pública", mas população subordinada e, sempre, plebe que murmura contra os excessos da predação colonialista, é um destina- 
tário composto como representação que testemunha a representação que lhe é oferecida ou imposta.

Buscadas à Ética a Nicômaco, as paixões do corpo são aplicadas ou racionalmente construídas mesmo quando são irracionais, tal como sua doutrina aparece em vários textos ibéricos, italianos e franceses do século XVII, como é o caso do tratado que o oratoriano Jean-François Senault dedica a Richelieu, em 1641, De l'usage des passions. A mecânica das paixões é aplicada segundo preceitos retóricos e jurídicos e o efeito resultante fixa o átimo em que uma ação deforma um gesto produzindo um afeto, como um instantâneo que congela o movimento selecionado em elencos prefixados de gestos: Degli effetti nascono gli affetti, como se dizia em Veneza no século XVII. Sendo construído como várias paixões sucessivas ou simultâneas, a que correspondem caracteres permanentes e transitórios, o corpo aparece diverso a cada momento, conforme o regime do artifício aplicado. Quando há simultaneidade de paixões, imediatamente há subordinação delas e dos caracteres secundários a um caráter ou paixão principais. Interessa referir, aqui, a estase, ou seja, a imagem que congela em um instantâneo a agitação do corpo pela paixão, como nos santos das igrejas, em cujas poses artificiosas Ulrich, o homem sem qualidades de Musil, vê a catatonia. No corpo efetuado se lê ou vê também a representação do processo produtor do efeito, ou seja, a presença de um mecanismo óptico que recicla as tópicas do ut pictura poesis horaciano e que faz o destinatário discreto lembrar-se do elenco de ações e da seleção feita pelo juízo do autor da representação quando calculou as distâncias adequadas para a observação da imagem, o número de vezes que deve ser vista e a maior ou menor clareza correspondente ao estilo aplicado. $\mathrm{O}$ mesmo mecanismo se acha nas letras como cálculo dos efeitos. As anamorfoses da pintura, por exemplo, correspondem às alegorias enigmáticas da poesia e da prosa. Em todos os casos, a representação teatraliza a memória de usos autorizados que a tornam também autorizada. Em todos os casos, as paixões nunca são expressivas ou psicológicas, mas retóricas, decorrendo de uma racionalidade formalizada numa técnica objetiva e assimetricamente partilhada de produzir efeitos. Não se trata nunca de exprimir conceitos, mas de teatralizá-los. O artifício mobiliza vários saberes, retórica, dialética, lógica, arte combinatória, ética, teologia, subordinando-os à noção generalizada de ordo, ordem, ou ratio, razão, figurada nas representações da "política católica" portuguesa como presença da luz natural da Graça inata nos negócios do Brasil e do Maranhão e Grão Pará.

Nas imagens agudas, a semelhança dos seres em relação ao Um divino é efetuada pela analogia de atribuição, que é uma relação lógica e intencional entre coisas; pela analogia de proporção, que é uma relação lógica e metafisicamente determinada dos entes a Deus; e pela analogia de proporcionalidade, que é uma relação lógica e metafisicamente inde- 
terminada. Logicamente, assim como é determinada a relação entre 2 e 4, pois são números pares próximos, um poeta pode escrever que a boca da amada é um cravo, pois são vermelhos, estabelecendo relação entre um gênero e suas espécies; é indeterminada a relação entre 2 e 27 , por exemplo, assim como é semanticamente indeterminada a metáfora de um soneto em que, emulando Góngora, Manuel Botelho de Oliveira propõe que serpente é maio. Embora 2 e 27 sejam convenientes como números, assim como serpente e maio convêm como nomes, não é imediatamente evidente a proporção lógica que os relaciona. Mas é justamente a proporcionalidade, que afirma uma semelhança indireta e uma distância infinita entre os seres criados e a identidade divina, assegurando aos atributos de Deus significado positivo e verdadeira realidade sempre aludidos na representação como um "para-além-da-presença-imediata" ou um sublime que atravessa as imagens, tornando-as alusivamente conformes ao Um, que se lê nas imagens hoje aparentemente incongruentes, afetadas e pedantes de Botelho de Oliveira, que comparam o movimento físico do réptil e o movimento incorporal do tempo.

Nas letras do século xviI - lembrando cinco dos maiores autores desse tempo, Quevedo, Góngora, Vieira, D. Francisco Manuel de Melo e Sor Juana Inés de la Cruz - a analogia de proporção e, principalmente, a analogia de proporcionalidade são tidas como os procedimentos metafísico-lógico-retóricos mais desejáveis para a invenção e a ordenação da representação, pois evidenciam a superioridade do engenho do intelecto agente dos autores, quando produzem o conceito engenhoso e, com isso, a presença irradiante da Luz que os ilumina no mundo. É também o caso, mais modesto, mas não menos significativo, dos sermōes pregados em Salvador em 1699 por Frei Antonio do Rosário, Frutas do Brasil, em que o amor de N.S. do Rosário é comparado a 25 frutas tropicais, extraindose de cada comparação uma virtude teologal, a figura de um sacramento e um mistério. Pode parecer irrisoriamente afetado hoje, mas encontra a razāo histórica também da sua afetação na especificidade de práticas lógica, dialética e metafisicamente fundamentadas. Aqui, como nos outros autores, as imagens são a circumscriptio definida por Santo Tomás de Aquino na Ética, 1,7: um esboço exterior do bonum finale hominis, quod est felicitas, o bem final do homem, a felicidade. A imagem é notificação de um conceito ou de uma coisa por meio das características que conceito e coisa dividem com outros conceitos e coisas participados na identidade da substância metafísica e não propriamente por seus atributos específicos. A representação é feita secundum quandam similitudinarium et extrinsecam quodammodo descriptionem, segundo certa descrição extrínseca das similitudes, exteriorizando o que fuit prius figuraliter determinatum, o que antes foi figuralmente determinado na mente. Como tudo se assemelha ao divino per ordinem ad unum, toda representação é saturada da Presença, mesmo aquelas obscenas, tidas hoje como sintomas da

Barroco, neobarroco e outras ruínas -57 
tara de homem pessimista e ressentido suposto autor delas, como as da sátira atribuída a Gregório de Matos, em que a virtude da persona satírica só pode vituperar vícios porque é participada pela Luz. Os mínimos fragmentos da forma da expressão e da forma do conteúdo - para falar retoricamente, dos verba da elocução e das res da invenção - são figurações exteriores dessas imagens interiores saturadas com a luz da Presença. E como retoricamente o que importa são os modos da imitação, ou seja, as maneiras como a imitação é feita, não propriamente as matérias em que as formas da imitação são recortadas, há continuidade entre falar, escrever, cantar, dançar, pintar, arquitetar, esculpir, musicar e gesticular como meios equivalentes que repetem, numa imagem exterior, a Presença acesa como a sindérese nas imagens mentais. Sendo análogas à identidade divina, as imagens assemelham-se também a todas as outras imagens reais e potenciais, pois também são efeitos e signos participantes da mesma Causa luminosa. Justamente por isso, os conceitos mais distantes podem ser aproximados e condensados como agudezas.

A linguagem das representações coloniais luso-brasileiras do século xvir é um corpus phantasticum onde a similitude prolifera. A representação formaliza nos estilos adequados aos vários gêneros a posição ou o ponto fixo do juízo do autor iluminado pela Graça no ato retórico da inventio. Numa típica circularidade de código, para poder receber adequadamente o efeito produzido na obra, o destinatário é situado segundo a perspectiva do mesmo ponto fixo da enunciação, aplicando-se à exegese da identidade divina parcialmente figurada ou, melhor dizendo, sublimada como prudência ético-política nos efeitos produzidos. Na aparência disparatada, múltipla e acumulada dos seres e eventos representados, o destinatário deve encontrar o fundamento divino justamente na prudência evidenciada pelo juízo da enunciação, quando ordena aguda e decorosamente os estilos ao fim hierárquico definido pelos gêneros retóricos. Como meio-termo racional que define discretos, a prudência é visível ou presentificada na técnica racionalmente aplicada à composição dos estilos da representação como causa formal da sua invenção. Quanto maior a agudeza, quanto maior a distância, quanto maior a incongruência aparente dos conceitos aproximados, mais se evidencia a Luz que aconselha o artifício técnico, segundo um preceito que Tesauro e outros preceptistas do tempo chamam de despropósito proposital e inconveniência conveniente.

Os principais tratados retórico-poéticos do século XVII ibérico e italiano e os textos de poetas, oradores e dramaturgos contemporâneos, que teorizam os modos mais adequados de figurar exteriormente a Presença transcendente que brilha como luz da Graça no interior da consciência, doutrinam as artes como theatrum sacrum, fórmula posta em circulação pelos jesuítas no século xvi. Não se trata de representação no sentido empirista do reflexo realista ou psicológico da expressão romântica encontráveis nos usos deduti-

$58 \neg$ João Adolfo Hansen 
vos de "barroco" "barroco histórico" e "neobarroco", mas de um pôr em cena dos rastros, vestígios e sombras fugidios da Presença no mundo. Um pôr em cena que dramatiza não só o definido da forma, no sentido do desenho claro e nítido da categoria "clássico", de Wölfflin, mas principalmente da sua labilidade e porosidade, de seus interstícios, corpúsculos e átomos irradiantes, em que formas tangenciam e atravessam formas, fundindo-se como espaços qualificados pela Presença. O principal princípio operatório das artes assim inventadas acha-se no acordo técnico entre ordem e ornato, ou entre o docere, a utilidade da disposição, e o delectare, o prazer do ornato. É justamente o engenho, uma "terceira faculdade" dialético-retórica, que produz a forma como agudeza ou efeito silogístico-retórico, que faz o acordo de argumento e imagem. O suposto "barroco" do estilo das representações não se confunde com o ornato, como em estudos estilísticos que reduzem "retórica" a figuras de estilo, generalizando transistoricamente a oposição romântica de "forma/conteúdo", para classificar as obras como "cultistas"53. É nuclear nas representações do século XVII o culto da dialética, realizado como decomposição analítica das tópicas da inventio e da dispositio. A dialética é a base do intelectualismo conceptista que inventa os discursos ora em variantes áticas, ora asiáticas. Mesmo o mais "cultista" dos discursos resulta da operação dialético-retórica. Não se trata de "formalismo", pois a retórica e a dialética aplicam-se a lugares ou tópicas, não a "formas" ou "conteúdos" generalizados transistoricamente.

Nas letras, depois que efetuam as qualificações dialéticas da matéria do discurso no ato da invenção e acham e definem, também dialeticamente, as principais tópicas adequadas ao gênero que vão produzir, os autores costumam ordená-las de modo paralelístico, espelhando-as como quiasmas, como nos versos atribuídos a Gregório de Matos, "Madrasta dos naturais/e dos estrangeiros Madre", de modo que a ordem sintática das partes, ab-ba, evidencia, a cada momento, as operações dialéticas aplicadas à definição e divisão das suas qualidades dispostas como argumentos. Genericamente, o discurso é "geométrico", dispondo-se como o "xadrez de palavras" dos sermões dominicanos que Vieira censura no sermão da Sexagésima, não por serem dialéticos, não por serem artifício, não por serem ornados, não por serem agudos, mas por serem aplicados pela ordem religiosa rival numa pragmática em que a agudeza se torna politicamente indecorosa, porque seu uso sem fundamento teológico não está previsto nas determinações

53 "Culto", no século XVII, não significa "formal" nem "formalista". O termo "culto" é usado por Quevedo, por exemplo, para desqualificar a poesia de Góngora, principalmente a Fábula de Polifemo e Galatéia e as Soledades como arte sem arte, pois Góngora trata assuntos humildes com estilo sublime. Em 1624, aparece na Espanha o termo "culterano", trocadilho com "luterano", para classificar a poesia de Góngora como heresia poética.

Barroco, neobarroco e outras ruínas -59 
do decreto do Concílio de Trento, Super lectione et praedicatione, de 17 de junho de 1546, que regulam o gênero popular próprio do púlpito. Também nas representações de Vieira, a disposição ordena teatralmente os procedimentos da dialética aplicados às matérias como análise e qualificação dos temas. Os enunciados são divididos, por exemplo, como formulações bimembres, trimembres, por vezes quadrimembres. Produzindo-os como anatomia ou análise das tópicas da inventio e das partes da dispositio, também os procedimentos técnicos da sua análise dos ornatos da elocução são encenados, do que decorre a estruturação especular da forma. Os ornatos, que figuram significações análogas às dos conceitos obtidos pela análise da matéria da inventio e da dispositio, são-lhes sobrepostos, duplicando-os como sinédoques de efeitos pictóricos. Não se trata nunca de expressão de conceitos, como disse, mas sempre de dramatização de conceitos por meio de técnicas objetivamente partilhadas. Fazendo a análise e a classificação das imagens da elocução com as dez categorias aristotélicas, os autores efetuam a maravilha, pois a aplicação permite aproximar conceitos de coisas distantes e detalhá-los pela enumeração de suas particularidades icásticas e fantásticas como substância, qualidade, quantidade, lugar, relação, tempo, situação, hábito etc.

Representação e público Mimética e judicativa, a representação dramatiza os temas para o destinatário, aplicando-lhes lugares-comuns da invenção e ornatos da elocução extraídos de elencos tradicionais do costume e de opiniões julgadas verossímeis dos campos discursivos e não-discursivos de práticas contemporâneas. A representação imprime-lhes maior ou menor deformação, que evidencia os modos técnicos de operação do juízo posto entre dois limites, o de uma clareza total, definida como vulgar, e o de uma obscuridade total, também vulgar. Há clarezas e obscuridades relativas e específicas de cada gênero, no plural, pois os conceitos são aplicados tecnicamente e não correspondem à expressão unívoca e imediata de uma idéia clara e distinta, como no cartesianismo, mas à dramatização de várias espécies de idéias, mais ou menos claras, compostas segundo as clarezas e os hermetismos específicos dos gêneros. Compondo o destinatário como avaliador da eficácia do que se representa, o juízo encenado nas agudezas evidencia a auctoritas da proporção que constrói o efeito, evidenciando também a sistematicidade da instituiçāo retórica, em que o "bem feito" é relacional, definindo-se posicionalmente ou negativamente como o que não pode ser retirado da forma nem acrescentado a ela. Assim, a representação também figura os critérios hierarquizadores da sua formulação, num modo que hoje se diria "metalingüístico" e que, no contrato enunciativo, constitui o destinatário como um sinônimo da enunciação ou um intelecto também conhecedor, quando discreto, do artifício técnico aplicado. O ponto de vista encenado na enunciação

$60 \neg$ João Adolfo Hansen 
não é uma categoria biográfica, como disse, mesmo quando se trata de carta familiar, mas o de uma enunciação conformada por uma racionalidade não-psicológica, uma racionalidade técnica, como um instrumento, entre outros, de representação de tipos compostos por caracteres retóricos e subordinados como necessidade à hierarquia. A escolha de determinada tópica, caráter, ação e, ainda, de determinada disposição dos argumentos, dentre os vários elencos prescritos pela instituição, é indicativa do modo como o agente do discurso posiciona na hierarquia o tipo que faz a enunciação, quando a situa como uma variante do sistema retórico-poético aplicado e preenche semanticamente suas tópicas com a variedade das significações dos discursos locais. Como a autoridade da instituição retórica é total, o ponto de vista não é autonomizado, pois é o de uma liberdade de aplicação de preceitos técnicos situada no intervalo que vai, em cada gênero, da inépcia à licença poética, segundo elencos de preceitos da elocução, da verossimilhança e dos decoros. A suposta "experiência subjetiva" do autor do discurso é parte do todo social objetivo, enfim; por isso, os modos da sua representação estão imediatamente relacionados com os meios de avaliação do campo institucional ou do campo semântico geral de seu tempo.

"Público" no caso, é a totalidade mística do corpo político figurada nas representações como "bem comum" do Estado. Incluído nela, cada destinatário produzido pela representação reconhece e deve reconhecer sua posição subordinada: a representação reproduz aquilo que cada membro do corpo místico já é, prescrevendo, ao mesmo tempo, que ele deve ser, ou seja, persuadindo-o a permanecer como o que já é. O espaço público figurado como totalidade mística de "bem comum" nas representações é como um teatro corporativista, enfim, onde se revela o próprio público para o destinatário particular como totalidade jurídico-mística de destinatários 54 integrados em estamentos e ordens subordinadas ao Estado. Justamente por isso, impõe-se a normatividade retórica, que pressupõe a repetição. Quando os esquemas retóricos e os temas de discursos contemporâneos encenados no discurso particular são apropriados por públicos de diversas competências - mas sempre incluídos nas normas hierárquicas do "bem comum" desse "corpo místico" - a recepção modela-se prescritivamente. Por outras palavras, os juízos da recepção também são normativos ou reprodutivos de regras: obedecem a padrões institucionais de ordenação e consumo das representações, refazendo, na leitura e na audição, os procedimentos aplicados à sua inventio. O campo semântico geral do autor, que recicla a auctoritas do gênero, e o do destinatário, que é efetuado como um sinônimo da enunciação, prescreve o uso de imagens extraídas de práticas contemporâneas, letradas e não-letradas, discursivas e não-discursivas, mas 
já conhecidas. Elas definem a experiência contemporânea como representações visualizantes que fazem variações das tópicas de gêneros segundo a experiência cultural acumulada neles e que eles, por sua vez, reativam como naturalidade da hierarquia.

No sermão da Sexagésima (1655), quando Vieira diz que o sermão dominicano é "negro boçal", a metáfora do hermetismo é extraída dos discursos do escravismo colonial, que no Estado do Brasil classificam o escravo como "boçal" ou "ladino" conforme fale ou não fale Português. A metáfora "negro boçal" remete a audição do destinatário do sermão à experiência cultural das imagens e prescrições da codificação jurídica que regula o escravismo e a posição do escravo no sistema colonial. A regulação jurídica, que é a do pacto de sujeição, tem fundamentação teológica e, por isso, a metáfora traça simultaneamente para o destinatário uma perspectiva avaliativa que amplifica pejorativamente a ação dos dominicanos, pois "negro boçal" significa o mais baixo da hierarquia e, ao mesmo tempo, a falta dos valores positivos da luz natural. No caso, a metáfora classifica teologicamente os "estilos cultos" dos dominicanos como falta pecaminosa do Bem jesuítico, estabelecendo semelhança entre a afetação do estilo, a ação tirânica dos dominicanos à frente do Santo Ofício e a "boçalidade" pressuposta coletivamente na idolatria também pressuposta do negro, como desqualificação própria de uma sociedade que acredita na "limpeza de sangue", na herança do pecado original, na língua adâmica, na naturalidade da hierarquia e do escravismo, no Céu e no Inferno e, obviamente, na naturalidade do pacto de sujeição e da classificação dos membros subordinados nele ao "bem comum", como critérios definidores da excelência humana e da sua representação discursiva. A metáfora classifica os "estilos cultos" dos dominicanos como vileza, gentilidade, idolatria e heresia, mandando-os, com a maravilhosa audácia típica de Vieira, para o Inferno, enfim. Ao fazê-lo, Vieira também ratifica a direção geral do programa póstridentino da oratória da Companhia de Jesus, que era o de uma imitação proporcionada de casos da história sacra oposta frontalmente à afetação das agudezas que se compraziam em evidenciar o seu próprio artifício retórico, tornando-se indecorosas para o púlpito, como ocorria na pregação apostilada dos religiosos de São Domingos. De todo modo, é útil reiterar que, nos efeitos de agudeza, o discurso propõe os critérios pelos quais o destinatário deve relacionar o veículo e o tema, a figuração e a matéria, encenando o ponto de vista para a apreciação adequada. Este é o ponto fixo da prudência, proposta ética e politicamente como feita à imagem e semelhança do Bem na regulação ajuízada da linguagem e do gênero da obra particular. Não seria necessário dizê-lo, a compreensão desses discursos é forçosamente lacunar, pois falta para sempre, felizmente, a experiência avaliativa do campo semântico geral do "bem comum" vivenciados misticamente por Vieira e seu público.

$62 \neg$ João Adolfo Hansen 
A agudeza típica das representações do século Xvil é tanto um processo poético quanto uma concepção da história. Não é um elemento que se possa autonomizar, na poesia ou na prosa, e reduzir a um dado estilístico, como uma aplicação ornamental exterior que deva ser desprezada a priori como acessória e afetada. Como um padrão generalizado da analogia metafísica e lógica implicada na relação finito/infinito que rege as práticas portuguesas do século XVII, a agudeza especifica uma forma histórica de pensamento, a da racionalidade de sociedades de Corte, modelando as práticas de representação como processo mimético que é simultaneamente avaliativo, evidenciando um juízo prudencial adaptado às ocasiōes da hierarquia. Trata-se de um uso da linguagem como forma histórica portadora de um sentido social e de uma força política independentemente dos significados que possa veicular55. Difundida a agudeza como modelo de todo o corpo político, suas aplicações particulares especificam o sujeito da enunciação dos textos como "entendido" nas virtudes político-retóricas, que o definem como capacidade de aplicar um decoro definido como modo imitativo ou mimético e, simultaneamente, judicativo ou avaliativo de sua própria prática e das matérias nela tratadas como protocolo da interpretação do "bem comum" fornecido ao destinatário. O que implica, de imediato, a dupla orientação dos discursos, que na metaforização aguda encenam também os critérios de sua inteligibilidade contemporânea, evidenciando imediatamente a partilha de referenciais comuns que distinguem, separam, classificam e posicionam hierarquicamente. Segundo a prescrição seiscentista, "melhor" é aquele que aparenta a representação adequada à sua posição na hierarquia, demonstrando que sabe seu lugar de membro subordinado ao "bem comum" Para mantê-la publicamente, ou seja, na esfera de sua subordinação livre ao "bem comum" definida como representação e pela representação de seus privilégios, espelha-se na pessoa mística do rei, cabeça do corpo político e ponto fixo, que reconhece sua representação de "melhor" por meio, justamente, dos privilégios que a fundam e fundamentam. Como a superioridade social do tipo é confirmada pelos signos ostensivos da sua submissão política e simbólica, seu ser social identifica-se à imagem da opinião feita sobre a sua representação, confirmando-se em sua posição com ela, se ela for adequada à posição nas várias circunstâncias da vida. A afetação ou a nãoafetação das representações é julgada, por isso, segundo critérios retóricos e teológicopolíticos específicos da hierarquia dessa formação histórica. E eles não são "barrocos" Ou seja: na figuração desses tipos e efeitos, não se encontram, em nenhum momento, as noções iluministas e pós-iluministas de "progresso" "evolução" "negatividade" "ideologia" "crítica" e "revolução" Não há "livre-concorrência" e "mercado cultural" Nem as 55 lbid., p. 193

Barroco, neobarroco e outras ruinas -63 
noções de "estética", "contemplação desinteressada", "expressão psicológica”, "originalidade", "ruptura", "racionalização negativa da forma". Nem um novo regime discursivo, a "literatura", oposto a outros regimes discursivos, como "ciência", "direito", "moral" "religião" "mitologia", "filosofia" e "história". Nem as noções de "autor" e "artista", como subjetivação psicológica, genialidade, crítica, plágio e propriedade de direitos autorais de obras concorrendo no mercado como originalidade heróico-cínica. Nem "mercado" ou "público", como "opinião pública" teoricamente dotada da representatividade democrática das várias particularidades de grupos de interesse. Nem as definições contemporâneas de "publicação" como edição de textos impressos dotados de intenção autoral, unicidade, originalidade e autenticidade. Nem a noção de "obra literária" como texto depositário de um sentido invariante, formulado como código lingüístico independente dos códigos bibliográficos.

Quando os modos coloniais de ordenar e figurar a experiência do tempo são reconstruídos, as categorias generalizadas transistoricamente pela aplicação a-crítica e dedutiva da classificação de "barroco" revelam-se anacrônicas. Também as "neobarrocas", que mantêm muitas categorias iluministas e românticas de "barroco" em novos usos, como formas esvaziadas de função teleológica.

Ruínas, neobarroco, barroco É pertinente considerar essas articulações para determinar o que, nas ruínas coloniais sintomaticamente classificadas como "barroco histórico", aparece hoje tão vivo a ponto de facultar as identificações do presente com um novo "barroco" ou um neo-romantismo que não mais seria "histórico" ou romântico, mas apenas "neobarroco", neo-neo-romântico, pós-moderno e "pós-utópico". É a tópica da metafísica, aparentemente imaterial, que permite determiná-lo. Os efeitos das artes do século XVII resultavam, em seu tempo, do substancialismo metafísico extinto desde a segunda metade do século XVIII. A temporalidade seiscentista é, como se viu, qualificada pela Presença divina, que orienta toda a história do Antigo Regime como alegoria providencialista de seus desígnios. A metafísica seiscentista não conhece, obviamente, o conceito iluminista de história, produzido a partir da segunda metade do século XVIII, que subordina quantitativamente o tempo ao processo histórico como o contínuo de superações progressistas rumo à realização final da Razão num futuro utópico em suas várias versões hegelianas e marxistas. O tempo seiscentista pressupõe, ao contrário, o retorno do passado sobre o presente, não como repetição simples do já ocorrido, mas como repetição da identidade do conceito indeterminado de Deus que torna semelhantes os eventos dos vários tempos, orientando-os, como diferenças de tempos históricos, à redenção final. Decorre disso o pensamento da similitude, que propõe a representação como o 
jogo da Presença que encena a Identidade nas semelhanças e diferenças dos seres e tempos metaforizados nos estilos.

Hoje, quando as utopias iluministas foram postas de lado, a analogia das produções contemporâneas com a representação seiscentista é determinada pelas novas formas que a experiência do tempo vem assumindo na troca generalizada. Agora o tempo também aparece como estacionário e "frio", porque o futuro, donde até ontem o moderno irrompia como negação revolucionária do presente, aparece bloqueado. No presente, em que ficou chato ser moderno, a cultura é a eternidade do arquivo que acumula tudo o que foi e é como multiplicidade disparatada de ruínas. A presença do presente não é nem pode ser Deus, que está definitivamente morto, mas a mercadoria, que torna o estético o anestésico alegorizante de um mesmo princípio universal, o capital. Agora, a história é o inverno da desesperança global, pois o futuro desapareceu da nossa competência, para lembrar Oswald de Andrade. A fantasmagoria do "barroco", que nunca houve, ressuscita, depois de três séculos em que as ruínas assim classificadas estiveram recalcadas e excluídas nos programas iluministas e pós-iluministas, como "neobarroco". Agora que o nacionalismo vindo do século XIX se dissolveu no fluxo global da mercadoria e suas versões etapistas são ruínas que persistem como a inércia da falta de teoria de si mesmas em regressões fundamentalistas, a noção reafirmada de uma unidade "barroca" transistórica do país decreta a naturalidade da conciliação harmônica de todos os interesses, como se a federação das diferenças correspondesse à de um metafísico corpo místico subordinado como "bem comum". Nos discursos do "neobarroco", produzido como acúmulo de estilemas de passados empilhados sem hierarquização do valor, a equivalência geral do valor estético dos simulacros da cultura-mercadoria se oferece à recepção como experiência desmaterializada da repetição do valor-de-troca. Quando se comparam as artes "neobarrocas" e as do século XVII, a experiência da desmaterialização do presente nelas assemelha-se à experiência metafísica da temporalidade seiscentista participante na Luz divina. A semelhança entre as artes do século xvir e as ditas "neobarrocas" e "pósutópicas" só pode ser produzida pela diferença histórica, evidentemente. Mas os discursos "neobarrocos" positivam e substancializam a semelhança, fixando-a como identidade transistórica ou a-histórica de "barroco". Logo, enquanto positivam as noções de "barroco" e "neobarroco" como desierarquização da historicidade dos objetos do passado, a mesma desistoricização constitui a cultura contemporânea como positividade da coexistência de todos os tempos, e assim também mimetiza o vazio metafísico da teologia-política das práticas do que vem sendo chamado "barroco histórico". Enquanto afirmam que a presença do presente é o "barroco" transistórico de uma "América barroca" ou um novo "barroco" não-histórico resultante de identificações analógicas e enfatizam 
alegremente o fim das assim chamadas meta-narrativas autoritárias do Iluminismo, confundindo stalinismo com marxismo, os discursos "neobarrocos" que recuperam "o barroco" são regressivos. Declaram abolir as unidades e as unificações ideológicas do Iluminismo, mas fazem a unidade recalcada retornar como unidade puramente formal e vazia do descontínuo irrepresentável da realidade contemporânea que, assim como Deus, encarna-se como coesão nos ectoplasmas sublime-paródicos de simulacros gongóricoheurísticos. Deus está morto, mas agora que o capital determina as políticas do signo e a economia é a metafísica generalizada que produz a miséria também da cultura como falta de reflexão e auto-evidência da generalização da troca, o vazio metafísico da teologia-política das representações seiscentistas torna-se a metáfora dos dispositivos "neobarrocos" do troca-troca geral. Eles são dispositivos efetivamente unificadores e vazios, operando positivamente não com a metáfora do Deus neo-escolástico do século XVII, mas com o outro princípio, que não é metáfora, embora formalmente semelhante a Deus, o princípio universal da equivalência da mercadoria.

João Adolfo Hansen é professor de Literatura Brasileira da Universidade de São Paulo e autor de Alegoria: construção e interpretação da metáfora [Atual, 1986], A sátira e o engenho. Gregório de Matos e a Bahia do século XVII [Cia. das Letras, 1989], entre outros.

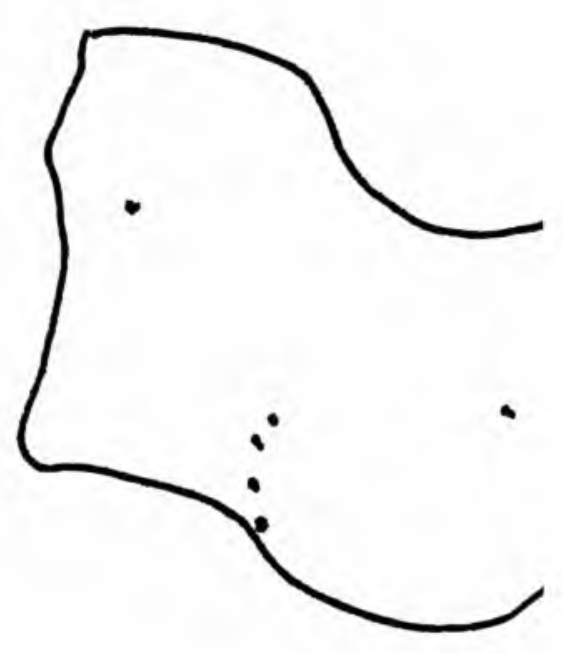




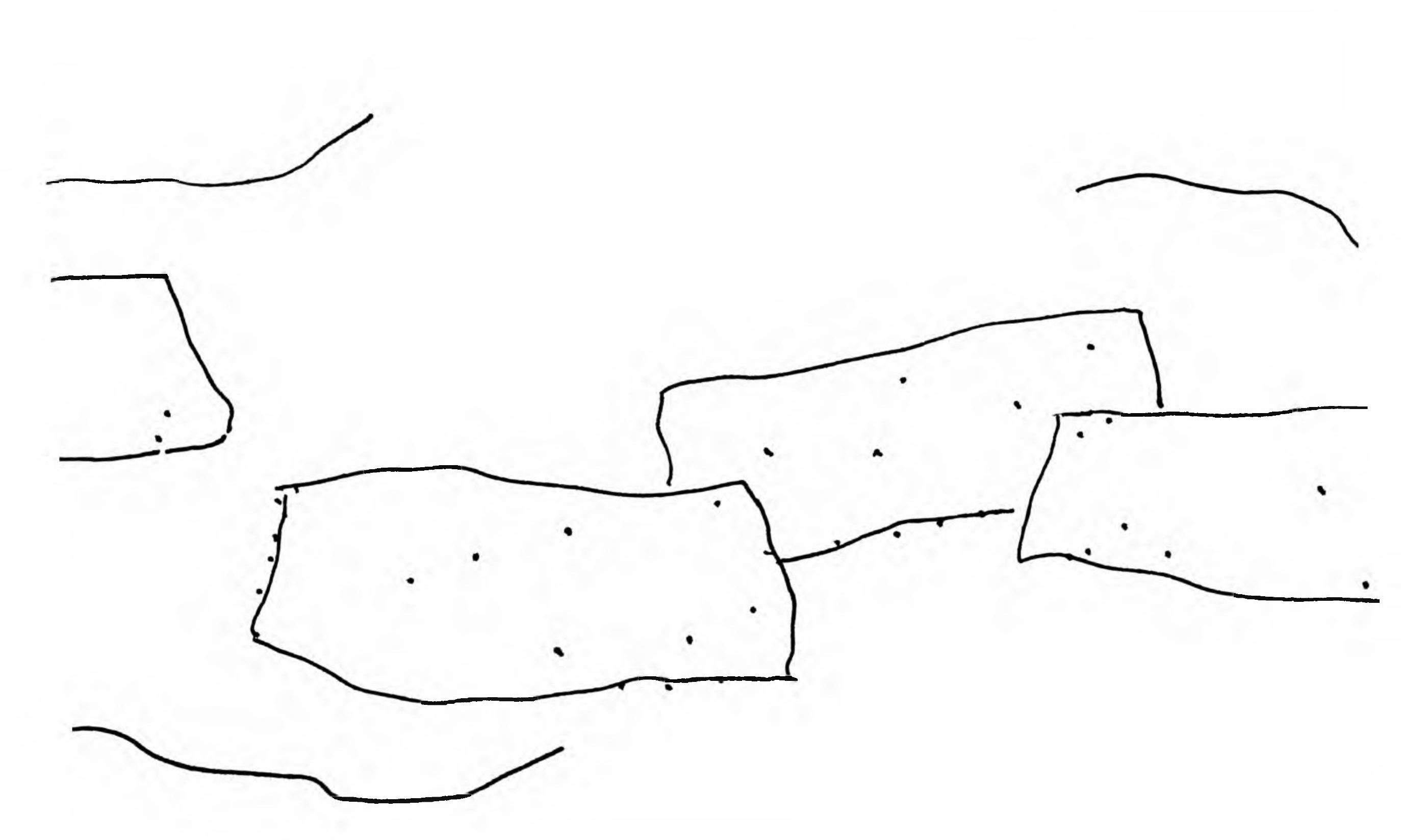

